\title{
PROCEDIMENTOS METODOLÓGICOS PARA A ANÁLISE DA EROSIVIDADE EM BACIAS HIDROGRÁFICAS: UM ESTUDO DE CASO DA BACIA HIDROGRÁFICA DO CÓRREGO MOEDA, TRÊS LAGOAS/MS
}

\author{
METHODOLOGICAL PROCEDURES FOR THE ANALYSIS EROSIVITY \\ IN HYDROGRAPHIC BASIN: A CASE STUDY OF HYDROGRAPHIC \\ BASIN OF STREAM MOEDA, TRÊS LAGOAS/MS
}

\author{
PROCEDIMIENTOS METODOLOGICAS PARA EL ANÁLISIS DE \\ EROSIVIDAD EN CUENCAS HIDROGRÁFICAS: UN ESTUDIO DE CASO DE \\ LA CUENCA HIDROGRÁFICA DEL ARROYO MOEDA, TRÊS LAGOAS/MS
}

\section{Rafael Brugnolli Medeiros}

Doutorando em Geografia pela Universidade Federal da Grande Dourados, UFGD, Brasil

Rua Oliveira Marques, 6035, apto: 501. Bairro: Jardim Guanabara, Dourados/MS. CEP: 79833-060. e-mail:rafael_bmedeiros@hotmail.com

\section{André Luiz Pinto}

Doutor em Geografia pela Unesp. Professor Adjunto IV vinculado ao Programa de Pós-graduação em Geografia da Universidade Federal de Mato Grosso do Sul, UFMS, Brasil; Av. Ranulfo Marques Leal n. 3484, Distrito Industrial, CEP 79:620-340, Caixa Postal n. 210.

e-mail:andrepinto@ufms.br

\section{Angélica Estigarribia São Miguel}

Mestre em Geografia pela Universidade Federal de Mato Grosso do Sul, UFMS, Brasil; Rua Roberto Rezende Telles, 1201. Bairro: Centro, Castilho/SP. CEP: 16920-000.

e-mail:angelica.esm@hotmail.com

\section{Weslen Manari Gomes}

Mestrando em Geografia pela Universidade Federal de Mato Grosso do Sul, UFMS, Brasil. Rua Dorindo Rodrigues do Amaral, número 319. Bairro Jardim Camargo, Brasilândia-MS, CEP: 79670-000.

e-mail:weslenmanari@hotmail.com

\section{RESUMO}

O objetivo desta pesquisa é avaliar a erosividade da bacia hidrográfica do córrego Moeda, localizada no município de Três Lagoas/MS, abordando a energia potencial erosiva pluviométrica, energia potencial erosiva do relevo e a energia erosiva do transporte de sedimentos em suspensão ao longo das estações de 2014. Para tanto, foi realizada a coleta ao longo de onze pontos de monitoramento das águas, além de analisar as precipitações da estação meteorológica da Fibria-MS Celulose Ltda; bem como, a velocidade de fluxo, 
vazão e transporte de sedimentos em suspensão. Os resultados obtidos apontam que os índices de erosividade variaram nas classes intermediárias, sendo possível visualizar que as classes alternaram conforme as chuvas e transporte de sedimentos, favorecendo esta variação e apontando índices mais elevados no verão e primavera. A abordagem das metodologias auxiliou na obtenção de um produto detalhado, retratando de forma concreta, a atual situação da área de estudo.

Palavras Chave: Erosividade; Transporte de Sedimentos; Precipitação; Energia Potencial Erosiva; Bacia Hidrográfica.

\section{SUMMARY}

The objective of this research is to evaluate the erosivity of the hydrographic basin of stream Moeda, in municipality of Três Lagoas/MS, addressing the potential energy erosive rainfall, potential energy erosive of relief and the erosive energy of the suspended sediment transport along the 2014 stations. Therefore, the collection was held for eleven water monitoring points, and analyzing precipitations of weather station Fibria-MS Celulose Ltda; as well as the flow speed, flow rate and sediment transport in suspension. The results indicate that the erosivity indices varied in the intermediate classes, and you can see that alternated classes as rainfall and sediment transport, favoring this variation and pointing higher rates in spring and summer. The approach of methodologies assisted in obtaining a detailed product, depicting concretely, the current situation of the study area.

Keywords: Erosivity; Sediment Transport; Precipitation; Energy Potential Erosive; Hydrographic Basin.

\section{RESUMEN}

El objetivo de este estudio es evaluar la erosividad de La cuenca hidrográfica del arroyo Moeda, en el municipio de Três Lagoas/MS, abordando la energía potencial erosiva de la precipitaciones, energía potencial erosiva del relieve y el energía erosiva del transporte de sedimentos en suspensión a lo largo de las estaciones de 2014. Por lo tanto, se realizó la recopilación de los once puntos de monitoreo de agua, y análisis de precipitaciones de estación meteorológica Fibria Celulose Ltda-MS; así como la velocidad de flujo, vaciamiento y transporte de sedimentos en suspensión. Los resultados indican que los índices erosividad de la variaron en las clases intermedias, y se puede ver que las clases se alternan como las precipitaciones y el transporte de sedimentos, lo que favorece esta variación y señalando tasas más altas en primavera y verano. El enfoque de metodologías ayudado a obtener un producto detallado, que representa concretamente, la situación actual de la zona de estudio.

Keywords: Erosividad; Transporte De Sedimentos; Precipitación; Energía Potencial Erosivo; Cuenca Hidrográfica. 


\section{INTRODUÇÃO}

A análise e gestão dos mananciais hídricos fornecem suporte para a compreensão do meio físico, biótico e antrópico, diagnosticando e avaliando os impactos causados pelas atividades humanas sobre a natureza, apontando para a necessidade de entender os processos que interferem na quantidade dos recursos hídricos, disponibilizando no sistema fluvial uma dissecação e transporte de sedimentos decorrentes da ação da água, bem como a diluição e assimilação dos contaminantes.

Uma das principais variáveis que alteram estes ambientes é a precipitação, Pereira et. al. (2002) afirmam que as atividades humanas são estritamente relacionadas às precipitações. Desta forma, é necessária o esforço para entender as condições e utilizá-las para resolver problemas ambientais, sociais e econômicos.

Portanto, as precipitações estão relacionadas aos desequilíbrios da paisagem, principalmente nas vertentes mais íngremes. A frequência destas chuvas acompanhada da alteração espacial da magnitude das precipitações (volume) são fatores primordiais a serem ponderados em circunstâncias críticas (desvios consideráveis na precipitação).

Outro importante fator que exerce uma influência direta sobre a quantidade e qualidade das águas e impõe diversas limitações de uso da terra, é a dinâmica erosiva do relevo, pois acompanha um padrão de ordem natural quanto à deposição e transporte de sedimentos, no momento em que o ambiente se encontra estável ou em equilíbrio dinâmico. Neste contexto, precipitações concentradas, coligadas aos altos declives, intemperismo acentuado e a falta de vegetação acabam criando áreas potencialmente propensas às erosões, acelerando o processo de degradação das bacias hidrográficas e prejudicando, principalmente, os ecossistemas aquáticos.

Diante destas constantes modificações que os ambientes estão propensos, esta pesquisa busca analisar a erosividade da Bacia Hidrográfica do Córrego Moeda, levando em conta conceitos de Tricart (1976), afirmando que os fenômenos erosivos incorporados no sistema podem ser analisados separadamente, em diversos subsistemas, de acordo com a escala que vai ser utilizada. Assim, cada microbacia terá características singulares, entretanto, as junções destes subsistemas provocam alterações na bacia hidrográfica com um todo.

Com isso, a presente pesquisa passou por diversas análises do relevo, como a Energia Potencial Erosiva do Relevo, que é um elemento físico constituinte desse sistema, sendo formado por um conjunto de estruturas interligadas e relacionadas ao relevo, abrangendo suas características como: Declividade, Dissecação Horizontal e Dissecação Verti- 
cal, significando, basicamente, o grau de erosão que uma bacia hidrográfica pode causar, de acordo apenas com seu relevo, não levando em consideração os demais aspectos como pluviosidade e a energia real desse relevo.

Posteriormente, a análise foi integrada com a precipitação e Energia Erosiva do Transporte de Sedimentos em Suspensão, que basicamente possui algumas variáveis, as quais são citadas por autores como Khnighton (1998) e Christofoletti (1976; 1981).

Esta carga é a energia que a bacia hidrográfica realmente carrega de sedimentos, abrangendo a geometria do canal, que é tridimensional, de acordo com Khnighton (1998), envolvendo largura, profundidade e declividade. Todas estas variáveis acabam condicionando a carga e descarga sedimentar.

Determinando assim, a Erosividade da BHCM, levando em consideração todos estes elementos e notar que cada um deles possui características que influenciam diretamente nos demais recursos naturais. Portanto é fundamental o entendimento de todos estes processos, objetivando um uso racional e sustentável dos ecossistemas.

A BHCM localiza-se no município de Três Lagoas/MS, que possui aproximadamente $10.206 \mathrm{~km}^{2}$, segundo dados do IBGE, situada a $330 \mathrm{~km}$ da Capital Campo Grande e a 680 km de São Paulo e pertence à mesorregião geográfica leste do Estado de Mato Grosso do Sul.

Situada na margem direita do Rio Paraná, portanto, a BHCM é considerada um subsistema do sistema Bacia Hidrográfica do Rio Paraná, possuindo uma área de 247,64 km² e posiciona-se entre as coordenadas UTM de 393200 e 425000 metros Oeste e 7676692 e 7696172 metros Sul, Figura 1. Localiza-se no sul da sede do município de Três Lagoas, a 26 km pela MS-395, no sentido a cidade de Brasilândia/MS. 
Figura 1: Localização da BHCM, Três Lagoas/MS.

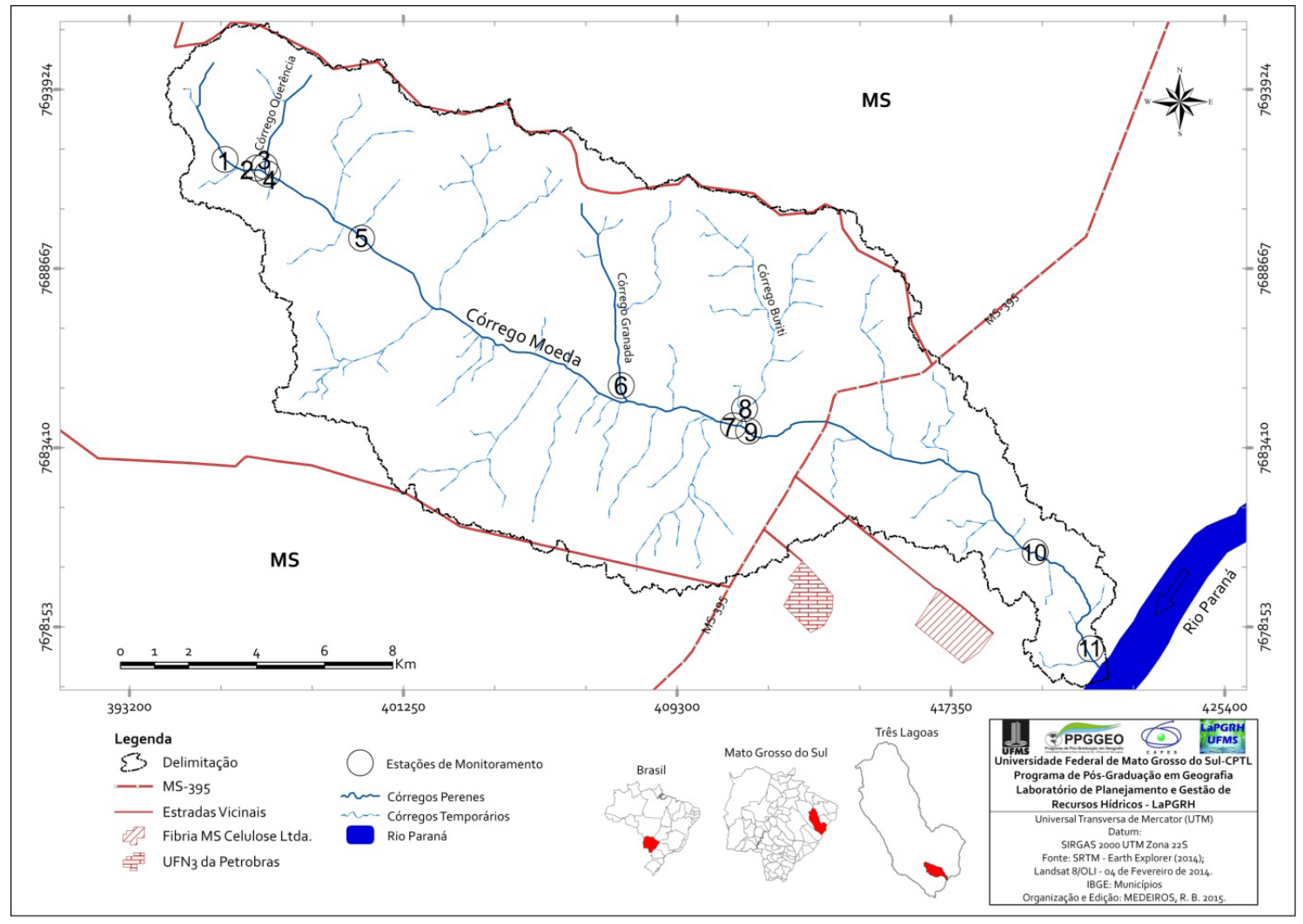

\section{OBJETIVOS}

O objetivo desta pesquisa é avaliar, por meio da junção de procedimentos metodológicos, a Erosividade da BHCM, analisando algumas etapas como a Energia Potencial Erosiva Pluviométrica (precipitação); Energia Potencial Erosiva do Relevo (declividade, dissecações horizontal e vertical); e a Energia Erosiva do Transporte de Sedimentos em Suspensão (velocidade de fluxo, vazão e transporte de sedimentos em suspensão).

A interpolação destas variáveis dar-se-á Erosividade, que será realizada durante as estações do verão, outono, inverno e primavera do ano de 2014, oferecendo assim, informações capazes de apontar a eficiência da metodologia utilizada, procurando abordar suas contribuições para a análise da Erosividade em bacias hidrográficas.

\section{METODOLOGIA}

Na proposta desta pesquisa, a Erosividade consiste em analisar alguns fatores que interferem na real e potencial perda de solo da BHCM, apresentando assim, algumas variáveis como a Energia Potencial Erosiva Pluviométrica, Energia Potencial Erosiva do Relevo e a Energia do Transporte de Sedimentos em Suspensão.

a 
O emprego e análise da Energia Potencial Erosiva Pluviométrica, é de extrema importância pois a precipitação é o elemento primordial de influência no processo de erosão hídrica, nos meses úmidos e quentes, geralmente haverá excesso hídrico, propiciando elevado potencial erosivo, passível de ser previsto pelo modelo proposto por Lombardi Neto e Moldenhauer (1992), modificado por Bertoni e Lombardi Neto (1999), que consiste em calcular a Erosividade das chuvas pelo índice numérico que expressa a capacidade da chuva em causar erosão em uma área sem proteção.

Para tanto, foram utilizados os dados da estação meteorológica da Fibria MS Celulose Ltda. Com a utilização destes dados, foram realizados os cálculos de Erosividade média mensal, utilizando a fórmula abaixo, com resultados gerados em MJ.mm/ha.

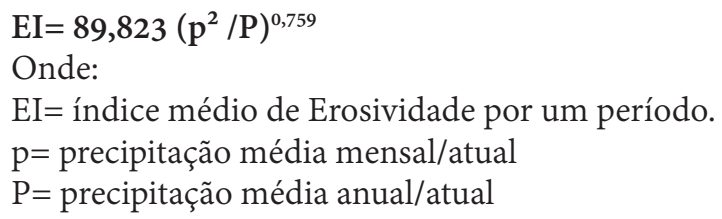

Os índices alcançados com a metodologia de Bertoni e Lombardi Neto (1999), foram classificados por meio de pesos para que possam ser interpolados com as demais variáveis desta pesquisa. Partindo do princípio de que, quanto maior a precipitação maior será o potencial erosivo, toda a elaboração dos pesos seguiu a metodologia de Crepani et. al. (2001), que analisa as classes de acordo com seu potencial de erosão.

Com relação à segunda variável de análise da Erosividade, a Energia Potencial Erosiva do Relevo torna-se imprescindível para a assimilação de alguns eventos que ocorrem em bacias hidrográficas, relacionadas ao relevo e possibilitam apontar seu potencial (qual a capacidade que a bacia carrega de sedimentos), definindo a possibilidade do risco e quais suas implicações ambientais.

Sua análise consiste na junção da dissecação horizontal e vertical e a declividade da BHCM, sendo necessária sua divisão em microbacias, juntamente com o prolongamento dos canais perenes, temporários e efêmeros, seguindo a metodologia de Spiridonov (1971) e Mendes (1993). Essas subdivisões dentro de um sistema auxiliam o pesquisador a obter uma escala determinada, sobretudo, na questão espacial.

A declividade foi obtida por meio do Serviço Geológico dos Estados Unidos, importando-as no SIG ArcGis 10, utilizando-se do módulo Spatial Analyst > Surface > Slope, para a criação da declividade em porcentagem da BHCM. As classes que foram determinadas seguem as metodologias de Lepsch (1983) e Ramalho Filho e Beek (1995). 
O mapa de Dissecação Horizontal e Vertical, que compreendem a metodologia de Spiridonov (1981), consiste da identificação das feições horizontais e verticais do relevo das bacias hidrográficas, levando em conta um ângulo de $90^{\circ}$ do curso fluvial até o divisor de águas das microbacias (Dissecação Horizontal) e de acordo com sua altitude em relação à linha do talvegue com o divisor de águas (Dissecação Vertical).

A junção destas três variáveis incidiu na análise da Energia Potencial Erosiva do Relevo, onde foram distribuídos pesos para cada classe temática, variando de Suavemente Suave à Forte, Tabela 1, identificando em apenas um documento, todos os dados morfométricos levantados nesta pesquisa, caracterizando a geometria da área estudada.

Tabela 1: Classes de Energia Potencial Erosiva do Relevo, de acordo com as variáveis: Declividade, Dissecação Horizontal e Dissecação Vertical da BHCM.

\begin{tabular}{lcccc}
$\begin{array}{c}\text { Classe de Energia Potencial } \\
\text { Erosiva do Relevo }\end{array}$ & $\begin{array}{c}\text { Declividade } \\
\text { (\%) }\end{array}$ & $\begin{array}{c}\text { Dissecação } \\
\text { Horizontal (metros) }\end{array}$ & $\begin{array}{c}\text { Dissecação } \\
\text { Vertical (metros) }\end{array}$ \\
\hline Suavemente Suave & 0,00 a 1,00 & $>1.500,00$ & 0,00 a 10,00 \\
\hline Moderadamente Suave & 1,01 a 2,00 & $1.000,01$ a $1.500,00$ & 10,01 a 20,00 \\
\hline Suave & 2,01 a 3,00 & 900,01 a $1.000,00$ & 20,01 a 30,00 \\
\hline Suavemente Fraca & 3,01 a 4,00 & 800,01 a 900,00 & 30,01 a 40,00 \\
\hline Moderadamente Fraca & 4,01 a 5,00 & 700,01 a 800,00 & 40,01 a 50,00 \\
\hline Fraca & 5,01 a 6,00 & 600,01 a 700,00 & 50,01 a 60,00 \\
\hline Suavemente Média & 6,01 a 7,00 & 500,01 a 600,00 & 60,01 a 70,00 \\
\hline Moderadamente Média & 7,01 a 8,00 & 400,01 a 500,00 & 70,01 a 80,00 \\
\hline Média & 8,01 a 9,00 & 300,01 a 400,00 & 80,01 a 90,00 \\
\hline Suavemente Forte & 9,01 a 12,00 & 200,01 a 300,00 & 90,01 a 100,00 \\
\hline Moderadamente Forte & 12,01 a 20,00 & 100,01 a 200,00 & 100,01 a 110,00 \\
\hline Forte & $>20,01$ & 0,00 a 100,00 & $>110,00$ \\
\hline
\end{tabular}

Com relação à análise da Energia Erosiva de Transporte de Sedimentos em Suspensão da BHCM, foi necessária a coleta de sedimentos em suspensão, bem como a vazão e velocidade dos canais fluviais. Estas coletas foram realizadas estacionalmente, durante o verão, outono, inverno e primavera de 2014. Os locais da coleta foram enumerados do ponto 1 até o ponto 11 e foram selecionados antecipadamente segundo critérios como: açude, captação de água pela Fibria MS Celulose Ltda.; montante, foz dos afluentes e jusante dos três principais córregos tributários (Querência, Granada e Buriti) e próximo da foz do próprio Córrego Moeda.

A mensuração da velocidade de fluxo e vazão das águas superficiais da BHCM só não foi realizada no ponto 1 , pois é localizado em um açude. Contudo, a vazão consiste no cálculo da área da cada estação de coleta, de acordo com as metodologias de Christofoletti (1980); Pinto (1985) e Pinto et. al. (2010), consistindo na mensuração da velocidade de fluxo do canal nas onze estações de monitoramento. 
Na elaboração da vazão, a área é mensurada por meio da elaboração de perfil transversal, com espaçamento de $10 \mathrm{em} 10 \mathrm{~cm}$, que depois de elaborado em ambiente AutoCAD 2012, calculou-se a área da seção do canal, em $\mathrm{m}^{2}$. Após este procedimento, os valores alcançados de área em $\mathrm{m}^{2}$ é multiplicado pelos valores da velocidade de fluxo, produzindo assim, os dados de vazão.

A mensuração do transporte de sedimentos em suspensão consistiu na coleta de amostras das águas superficiais ao longo dos mesmo onze pontos estabelecidos na BHCM. A periodicidade do monitoramento será trimestral, compreendendo todas as estações pretendidas (verão, outono, inverno e primavera de 2014). A carga de sedimento em suspensão pelos cursos fluviais é obtida pela ação erosiva que as águas desempenham sobre a bacia hidrográfica e o fundo dos leitos, especialmente.

Para a mensuração utilizou-se das metodologias descritas por Christofoletti (1980); Pinto (1985) e Pinto et. al. (2009), que consiste na análise em laboratório, onde os frascos foram agitados e colocados, $100 \mathrm{ml}$, em conjunto de infiltração da milipore, com filtro de 4,7 microns de celulose, que em seguida foram à estufa de secagem por 24 horas a $60^{\circ} \mathrm{C}$. Logo após resfriarem os filtros foram pesados em balança de precisão e compará-los com o peso de seus respectivos filtros sem sedimentos, como os valores correspondem a $100 \mathrm{ml}$, estes foram convertidos para $\mathrm{m}^{3}$ e calculados os valores conforme as vazões mensuradas.

Esta análise da carga de sedimentos fornece dados para a elaboração do mapa de Energia Erosiva de Transporte de Sedimentos em Suspensão, levando em consideração a metodologia de Pinto et. al. (2010). Esta metodologia fornece valores maiores dos obtidos para esta bacia hidrográfica, portanto, buscando uma melhor aplicabilidade para esta área, foram realizadas pequenas adaptações seguindo um padrão, principalmente nas classes, que foram divididas em doze classes e foi realizada uma divisão das classes de $1 \mathrm{em} 1 \mathrm{~g} / \mathrm{m}^{3} / \mathrm{s}$.

Com a junção de todas as variáveis analisadas, é possível identificar a Erosividade BH$\mathrm{CM}$, mostrando detalhadamente as formas do terreno, incluindo declividades, dissecação horizontal, dissecação vertical, o potencial erosivo pluvial, a capacidade de transporte de sedimentos e vazão das águas superficiais, ou seja, é a junção dos mapas de Energia Potencial Erosiva Pluviométrica, Energia Potencial Erosiva do Relevo e Energia Erosiva de Transporte de Sedimentos em Suspensão.

Com isso, sua análise foi realizada de forma estacional, demonstrando as influências das precipitações ocorridas no ano de 2014 e suas interferências na velocidade e vazão das águas e transporte de sedimentos em suspensão, Tabela 2. 
Tabela 2: Classes de Erosividade, de acordo com as variáveis analisadas na BHCM.

\begin{tabular}{|c|c|c|c|}
\hline $\begin{array}{l}\text { Classes de } \\
\text { Erosividade }\end{array}$ & $\begin{array}{c}\text { Energia } \\
\text { Potencial Erosiva } \\
\text { Pluviométrica (mm) }\end{array}$ & $\begin{array}{l}\text { Energia Potencial } \\
\text { Erosiva do Relevo }\end{array}$ & $\begin{array}{l}\text { Energia Erosiva } \\
\text { de Transporte de } \\
\text { Sedimentos em } \\
\text { Suspensão }\left(\mathrm{g} / \mathrm{m}^{3} / \mathrm{s}\right)\end{array}$ \\
\hline Suavemente Suave & $<10,00$ & Suavemente Suave & 0,00 a 1,00 \\
\hline Moderadamente Suave & 10,01 a 25,00 & Moderadamente Suave & 1,01 a 2,00 \\
\hline Suave & 25,01 a 50,00 & Suave & 2,01 a 4,00 \\
\hline Suavemente Fraca & 50,01 a 75,00 & Suavemente Fraca & 4,01 a 6,00 \\
\hline Moderadamente Fraca & 75,01 a 125,00 & Moderadamente Fraca & 6,01 a 10,00 \\
\hline Fraca & 125,01 a 200,00 & Fraca & 10,01 a 15,00 \\
\hline Suavemente Média & 200,01 a 250,00 & Suavemente Média & 15,01 a 20,00 \\
\hline Moderadamente Média & 250,01 a 325,00 & Moderadamente Média & 20,01 a 25,00 \\
\hline Média & 325,01 a 375,00 & Média & 25,01 a 30,00 \\
\hline Suavemente Forte & 375,01 a 450,00 & Suavemente Forte & 30,01 a 35,00 \\
\hline Moderadamente Forte & 450,01 a 500,00 & Moderadamente Forte & 35,01 a 40,00 \\
\hline Forte & $>500,01$ & Forte & $>40,01$ \\
\hline
\end{tabular}

\section{RESULTADOS}

A Energia Potencial Erosiva Pluviométrica leva em conta as prévias climatológicas mensais e as precipitações atuais. Dessa forma, essa análise foi realizada de maneira estacional, levando-se em conta todos os meses do ano de 2014. Com isso, a visualização das cores temáticas acabou facilitando o entendimento dos meses e estações úmidas e secas, utilizando-se destas informações para uma futura correlação com demais Mapas.

A Tabela 3 e Figura 2 mostram a Energia Potencial Erosiva Pluviométrica da BHCM ao longo das prévias climatológicas e no ano 2014, sendo possível a visualização das variações das precipitações e da energia potencial erosiva pluviométrica, apontando, assim, os locais mais passíveis de erosões.

Estes valores acabam definindo uma variação no potencial erosivo ao longo do ano, sendo importante para o planejamento das práticas conservacionistas de uso da terra a serem implementadas nas bacias hidrográficas, principalmente para a estimativa das perdas de solo para os leitos de córregos, rios e riachos por carregamento, o que pode, por sua vez, causar assoreamentos, ravinas e voçorocas, prejudicando não só o ambiente, mas também os produtores rurais, visto que um dos motivos para a redução da competência produtiva do solo é a erosão, que acaba diminuindo sua fertilidade e implica na rentabilidade das culturas. 
Tabela 3: Energia potencial erosiva pluviométrica e precipitação na BHCM, no período de 1983 à 2014 e de 2014.

\begin{tabular}{|c|c|c|c|c|c|c|c|c|c|}
\hline \multirow[t]{2}{*}{ Estação } & \multirow[t]{2}{*}{ Meses } & \multirow{2}{*}{$\begin{array}{l}\text { Prévia } \\
1983 \text { à } \\
2014\end{array}$} & \multirow[t]{2}{*}{2014} & \multicolumn{2}{|c|}{$\begin{array}{c}\text { Erosividade (MJ. } \\
\text { mm/ha) }\end{array}$} & \multicolumn{2}{|c|}{$\begin{array}{l}\text { Erosividade } \\
\text { (Milhões de } \\
\text { MJ.mm/bacia) }\end{array}$} & \multicolumn{2}{|c|}{$\begin{array}{l}\text { Erosividade } \\
\qquad(\%)\end{array}$} \\
\hline & & & & Prévia & 2014 & Prévia & 2014 & Prévia & 2014 \\
\hline \multirow{4}{*}{ Verão } & Janeiro & 227,19 & 121,16 & 1471,46 & 659,95 & 36,44 & 16,34 & 21,75 & 11,83 \\
\hline & Fevereiro & 187,22 & 87,37 & 1096,79 & 401,75 & 27,16 & 9,95 & 16,21 & 7,20 \\
\hline & Março & 162,29 & 85,34 & 882,9 & 387,67 & 21,86 & 9,60 & 13,05 & 6,95 \\
\hline & $\begin{array}{l}\text { Total } \\
\text { Verão }\end{array}$ & 576,70 & 293,87 & 3451,15 & 1449,37 & 85,46 & 35,89 & 51,01 & 25,98 \\
\hline \multirow{4}{*}{ Outono } & Abril & 92,85 & 121,67 & 378,25 & 664,17 & 12,37 & 13,45 & 7,38 & 9,74 \\
\hline & Maio & 56,75 & 45,21 & 179,35 & 147,78 & 4,44 & 3,56 & 2,65 & 2,58 \\
\hline & Junho & 26,58 & 5,84 & 56,64 & 6,12 & 1,40 & 0,16 & 0,84 & 0,12 \\
\hline & $\begin{array}{l}\text { Total } \\
\text { Outon }\end{array}$ & 176,18 & 172,72 & 614,24 & 818,07 & 18,21 & 17,17 & 10,87 & 12,43 \\
\hline \multirow{4}{*}{ Inverno } & Julho & 20,01 & 98,80 & 36,81 & 484,18 & 0,91 & 12,99 & 0,54 & 9,40 \\
\hline & Agosto & 23,99 & 0,00 & 48,48 & 0,00 & 1,20 & 0,00 & 0,72 & 0,00 \\
\hline & Setembro & 71,43 & 120,65 & 254,03 & 655,74 & 6,29 & 16,34 & 3,75 & 11,83 \\
\hline & $\begin{array}{l}\text { Total } \\
\text { Inverno }\end{array}$ & 115,43 & 219,45 & 339,32 & 1139,92 & 8,40 & 29,33 & 5,01 & 21,23 \\
\hline \multirow{5}{*}{ Primavera } & Outubro & 98,01 & 125,72 & 410,62 & 698,02 & 10,17 & 17,29 & 6,07 & 12,52 \\
\hline & Novembro & 142,94 & 177,03 & 728,14 & 1173,56 & 18,03 & 29,06 & 10,76 & 21,04 \\
\hline & Dezembro & 187,66 & 71,88 & 1100,7 & 298,75 & 27,26 & 7,40 & 16,27 & 5,36 \\
\hline & $\begin{array}{l}\text { Total } \\
\text { Primavera }\end{array}$ & 428,61 & 374,63 & 2239,46 & 2170,33 & 55,46 & 53,75 & 33,10 & 38,91 \\
\hline & Total & 1296,90 & $1.060,67$ & 6644,17 & 5577,69 & 167,53 & 136,14 & 100,00 & 100,00 \\
\hline
\end{tabular}


Figura 2: Energia potencial erosiva pluviométrica e precipitação de acordo com as prévias climatológicas da BHCM.

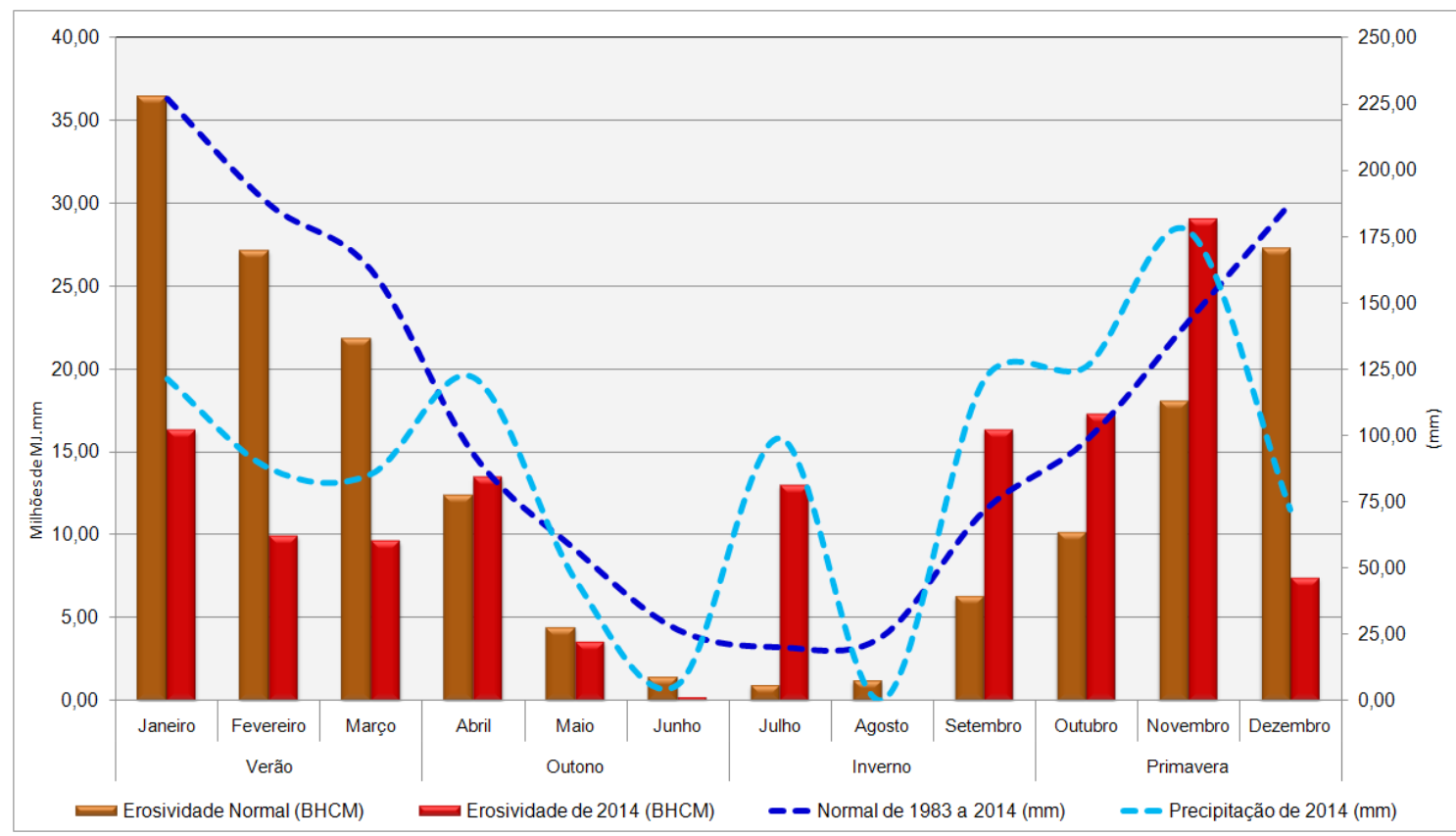

A precipitação no ano de 2014 foi considerada atípica, com isto sua energia potencial erosiva pluviométrica apresentou queda significativa com relação às prévias climatológicas. Lembrando que isto não é necessariamente uma variável apropriada, pois mesmo ocorrendo pouca Erosividade, o solo acaba ficando ressecado devido à falta de chuvas e uma pluviosidade muito alta em um curto espaço de tempo, e que poderá ser prejudicial.

Por meio destes índices, nota-se que a maior Erosividade é a registrada no mês de janeiro, pois possui a maior quantidade de pluviosidade, $227,19 \mathrm{~mm}$, fazendo com que ocorresse 36,44 Milhões de MJ.mm/bacia de energia potencial erosiva pluviométrica, representando 22,15\% do total. No ano de 2014, as precipitações foram menores com relação à prévia, fazendo com que os valores registrassem uma redução, chegando a 16,34 Milhões de MJ.mm na BHCM.

Em fevereiro permanecem as pluviosidades elevadas, assim como em março, com $187,22 \mathrm{~mm}$ e $162,29 \mathrm{~mm}$ respectivamente. Com isto, a Erosividade representou índices de 27,16 Milhões de MJ.mm em fevereiro e 21,86 Milhões de MJ.mm em março. Os índices destes meses do verão representam mais da metade de toda a Erosividade ocorrida na BHCM, de acordo com a prévia climatológica. Durante o ano de 2014, o mês de fevereiro e março representaram 9,95 Milhões de MJ.mm e 9,60 Milhões de MJ.mm respectivamente, ocasionado pelas reduções das precipitações durante estes meses. 
Com os meses chuvosos, a precipitação se distribui no solo superficialmente e em seu interior de forma mais acelerada. Na medida em que a superfície não é saturada, ocorre a infiltração. Entretanto, com o passar dos meses chuvosos, este solo vai se saturando e o excesso da pluviosidade ocasiona um escoamento superficial (transporte das partículas), provocando um aumento da energia potencial erosiva. O diferencial ocorreu durante o ano de 2014. O verão, que préviamente é chuvoso, representou uma queda significativa das precipitações, reduzindo também sua Erosividade pluviométrica.

Com a prévia climatológica e a chegada das estações mais secas (outono e inverno) ocorre uma inversão nos índices erosivos, apresentando valores mais reduzidos. O mês de abril apresenta 92,85mm de precipitação média, e isto representa 9,37 MJ.mm de potencial erosivo pluviométrico na BHCM. Nos meses seguintes (maio e junho) ocorre uma redução significativa nas precipitações, fazendo com que os índices de Erosividade alcancem 4,44 MJ.mm e 1,40 MJ.mm respectivamente. Um fator preocupante é que o outono (prévia) já é considerado seco, entretanto, no ano de 2014, este índice apresentou números mais reduzidos, o que diminuiu a Erosividade, mas também acaba deixando o solo mais ressecado, podendo ser prejudicial com a vinda de precipitações altas em curtos períodos de tempo.

Pouco antes da chegada do inverno é possível ver que as pastagens já se encontram ralas e batidas, o que proporciona uma energia potencial erosiva alta. Contudo, devido às suas precipitações reduzidas, acabam não provocando grandes perdas de solo. Entretanto, com a chegada do inverno chuvoso de 2014, acaba ocorrendo uma maior suscetibilidade à ocorrência da retirada na camada superficial do solo, mas que nesta estação acabou não sendo influenciável no transporte de sedimentos, como veremos adiante.

Os valores de energia potencial erosiva pluviométrica ficaram mais evidentes na primavera, pois ocorreu uma constante chuva, desde o inverno com julho e setembro chuvosos, permanecendo até a primavera com outubro e novembro chuvosos, ocorrendo, assim, a maior energia potencial erosiva pluviométrica, tanto pela prévia climatológica como também pelo ano de 2014.

Com isto, esta análise fornece dados que auxiliam na agricultura, plantio e, principalmente, corte dos hortos dos eucaliptos presentes na BHCM. Dessa forma, esta análise envolvendo a precipitação, precisa estar atrelada à análise do relevo da BHCM, fornecendo importantes informações que apontaram qual mês e sob qual característica de relevo, ocorrerá uma perda de solos mais intensa.

Assim, com a Declividade, Figura 3 e Tabela 4 é possível a identificação das áreas ocupadas por um determinado intervalo de declive e, consequentemente, quantificar essas áreas e elaborar pesos para que possam servir de instrumento na análise do mapa Síntese de Energia Potencial Erosiva do Relevo da BHCM, visualizando, assim, as classes que, obtendo uma melhor visualização, auxilia na quantificação e análise do mapa. 
Figura 3: Mapa de declividade da BHCM, Três Lagoas/MS.

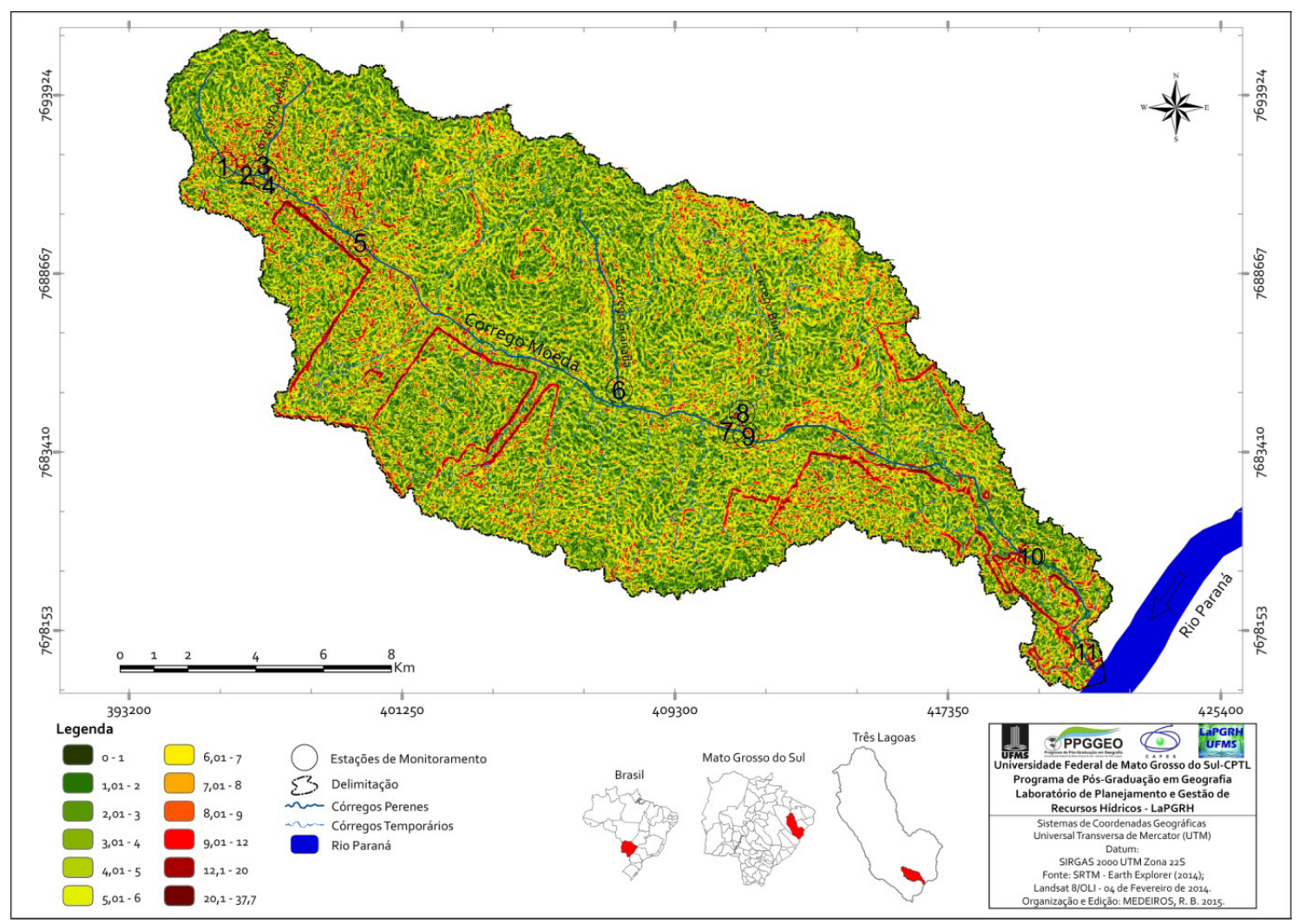

Tabela 4: Classes de declividade e facilidade na ocupação rural na BHCM, Três Lagoas, MS.

\begin{tabular}{|c|c|c|c|c|}
\hline $\begin{array}{l}\text { Declividade } \\
(\%)\end{array}$ & Classificação & $\begin{array}{l}\text { Área } \\
\left(\mathrm{Km}^{2}\right)\end{array}$ & $\begin{array}{c}\text { Área } \\
(\%)\end{array}$ & Facilidades na Ocupação Rural \\
\hline 0,00 a 1,00 & \multirow{3}{*}{$\begin{array}{l}\text { Plano a Muito } \\
\text { Suave }\end{array}$} & 10,84 & 4,38 & Aquicultura \\
\hline 1,01 a 2,00 & & 30,25 & 12,22 & \multirow{2}{*}{ Apto a qualquer uso agrícola } \\
\hline 2,01 a 3,00 & & 38,84 & 15,68 & \\
\hline 3,01 a 4,00 & \multirow{3}{*}{ Suave } & 44,97 & 18,16 & \multirow{3}{*}{$\begin{array}{l}\text { Depende da subclasse, pois será preciso } \\
\text { ações de controle erosivo ou de melhoria } \\
\text { na fertilidade do solo. }\end{array}$} \\
\hline 4,01 a 5,00 & & 36,48 & 14,73 & \\
\hline 5,01 a 6,00 & & 31,40 & 12,68 & \\
\hline 6,01 a 7,00 & \multirow{3}{*}{$\begin{array}{l}\text { Suave a Suave } \\
\text { Ondulado }\end{array}$} & 19,97 & 8,06 & \multirow{3}{*}{$\begin{array}{l}\text { Restrita a agricultura, mas apta para } \\
\text { agricultura moderna desde que use } \\
\text { técnicas de manejo e conservação do solo. }\end{array}$} \\
\hline 7,01 a 8,00 & & 13,51 & 5,46 & \\
\hline 8,01 a 9,00 & & 7,69 & 3,11 & \\
\hline 9,01 a 12,00 & $\begin{array}{l}\text { Suave } \\
\text { Ondulado a } \\
\text { Ondulado }\end{array}$ & 8,94 & 3,61 & $\begin{array}{l}\text { Susceptibilidade a erosão e perda de } \\
\text { potencial produtivo do solo. Permite } \\
\text { pastoreio, reflorestamento ea manutenção } \\
\text { da vegetação natural. }\end{array}$ \\
\hline 12,01 a 20,00 & Ondulado & 4,02 & 1,62 & $\begin{array}{l}\text { Não permite uso agrícola, somente } \\
\text { manutenção da vegetação original. }\end{array}$ \\
\hline$>20,01$ & $\begin{array}{c}\text { Forte } \\
\text { Ondulado } \\
\end{array}$ & 0,73 & 0,29 & Manutenção da vegetação original. \\
\hline
\end{tabular}

Fonte: Adaptada da Classificação de Lepsch (1983) e das Classes de Facilidades na Ocupação Rural, de Ramalho Filho e Beek (1995). 
A análise dos dados do mapa de declividade, Figura 3 e Tabela 4, apontou que a maior distribuição de declive se concentra nas classes de 3,01\% a 6,00\%, que remonta 45, $57 \%$ da Bacia, classificado como relevo Suave e que, de acordo com Ramalho Filho e Beek (1995), é um ambiente onde será preciso adotar ações de controle erosivo ou de melhoria na fertilidade do solo.

A classe de 3,01\% a 6,00\% abrangeu áreas ao longo de toda a Bacia, sobretudo no médio curso. No total, somou 112,85 $\mathrm{km}^{2}$ da BHCM, sendo classificada sua Energia Potencial Erosiva do Relevo, com pesos de 4 a 6.

A segunda classe mais encontrada na BHCM foi de 0,00\% a 3,00\% de declividade, com $79,93 \mathrm{~km}^{2}$ ou $32,28 \%$, sendo classificada como Plano a Muito Suave, e encontrada ao longo de toda a área da BHCM. A classe está apta a qualquer uso agrícola, segundo Ramalho Filho e Beek (1995), contudo, De Biase (1993 apud PINTO et. al., 2005) aponta pequenas limitações de usos agrícolas, principalmente por ser uma classe pouco acidentada, ocasionando, em alguns casos, inundações das planícies e apresentam um excedente hídrico que pode perdurar por alguns meses.

A classe de 6,01\% a 9,00\% abrangeu locais dispersos ao longo da BHCM, apontando para um total de $41,17 \mathrm{~km}^{2}$ ou $16,63 \%$ da área. Esta classe, segundo Ramalho Filho e Beek (1995), é restrita à agricultura, contudo, é apta à agricultura moderna desde que ocorra a utilização de técnicas de manejo e conservação do solo.

A classe $9,01 \%$ a $12,00 \%$ de declividade foi encontrada em poucas áreas, entretanto ao longo de toda a bacia hidrográfica, alcançando $8,94 \mathrm{~km}^{2}$ ou $3,61 \%$ da área total da $\mathrm{BH}$ CM. Estas áreas, segundo Lepsch et. al. (2002), são indicadas ao plantio de culturas anuais, sendo recomendadas práticas de conservação do solo.

Na Figura 4 é visualizada uma área que, além de apontar um declive de 9,01 a 12,00\%, é ocupada por pastagens sem curvas de nível ou qualquer tipo de manejo da terra, sendo apontada como um agravante devido ao seu gradiente de inclinação. Ramalho Filho e Beek (1995) consideram como uma classe onde ocorre uma susceptibilidade à erosão e perda de potencial produtivo do solo, permitindo apenas o pastoreio, o reflorestamento e a manutenção da vegetação natural. 


\section{Figura 4: Alto curso da BHCM, ao fundo, área de pastagem alcançando a classe de 9,01 a 12,00\% de declividade.}

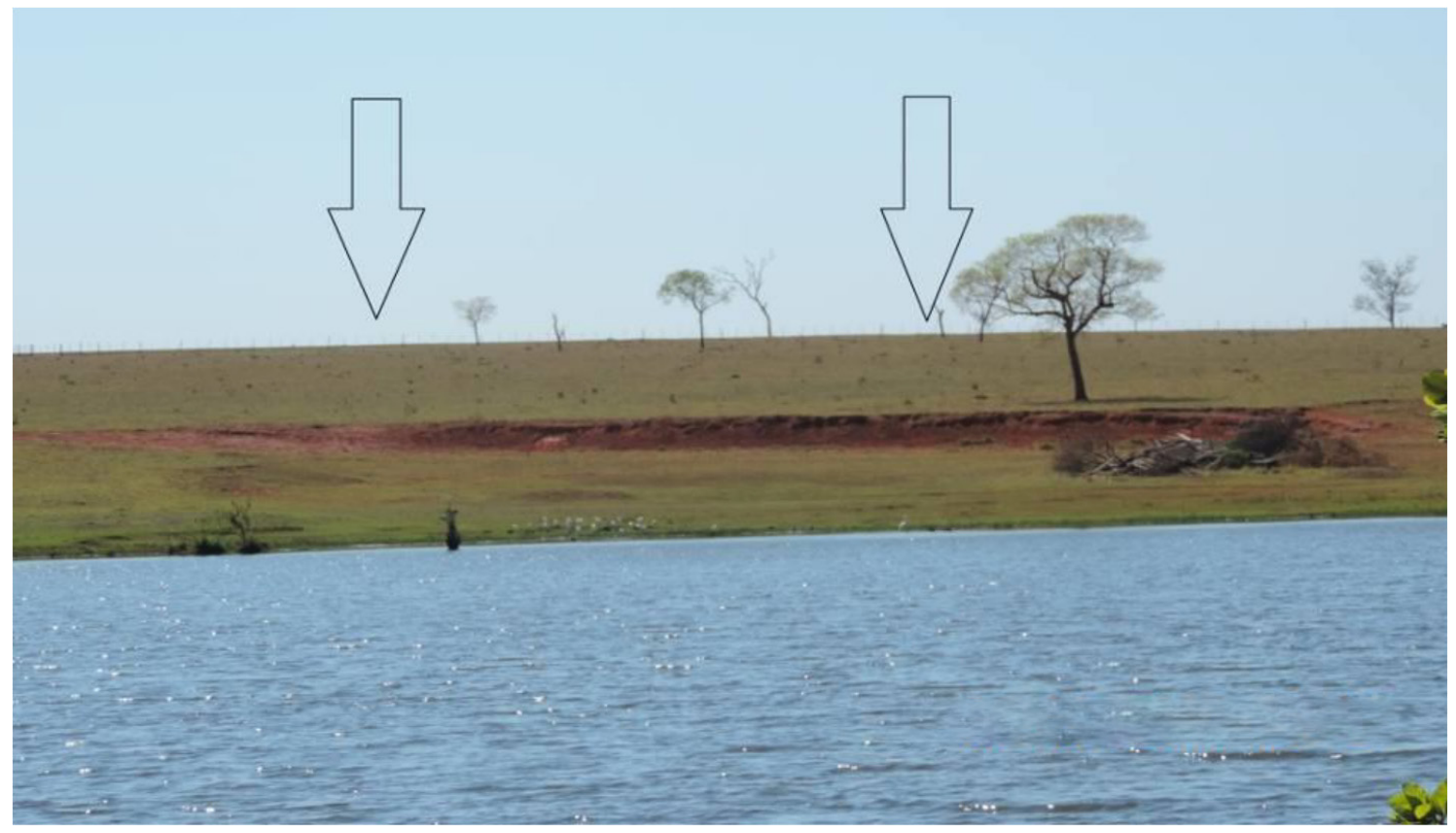

A declividade, quando alcança 12,01\% a 20,00\%, segundo Lepsch et. al. (2002), possuem maiores problemas erosivos e são impróprias para culturas anuais, apenas podendo ser utilizadas para culturas perenes, desde que busquem proporcionar uma proteção maior ao solo. Entretanto, Ramalho Filho e Beek (1995) afirmam que a partir desta classe de declive, as recomendações são para a não utilização agrícola, mas apenas manutenção da vegetação primitiva.

A classe $>20,01 \%$ de declive é classificada como Forte Ondulada e se apresentou com apenas $0,73 \mathrm{~km}^{2}$, que, segundo a classificação de Ramalho Filho e Beek (1995), devem ser utilizadas apenas visando a manutenção da vegetação natural. Esta classe, por apresentar a maior Energia Potencial Erosiva do Relevo da BHCM, foi classificada com Peso 12.

Na elaboração do mapa de Dissecação Horizontal da BHCM, ficaram evidenciadas doze classes, de acordo com a distância percorrida do canal fluvial até o limite da bacia hidrográfica, seguindo sempre uma linha reta. Portanto, cada uma das doze classes oferecem um peso distinto sobre o mapa de Energia Potencial Erosiva do Relevo, partindo do Peso 12 ao Peso 1, onde as maiores dissecações horizontais (em extensão) apresentam uma rampa mais suave, reduzindo seu potencial erosivo.

Com a Figura 5 é possível à identificação das classes, obedecendo às cores temáticas, de acordo com Spiridonov (1981), e na Tabela 5 são representados os valores obtidos em $\mathrm{km}^{2}$ e porcentagem para cada classe na BHCM. 
Figura 5: Mapa de dissecação horizontal da BHCM, Três Lagoas/MS.

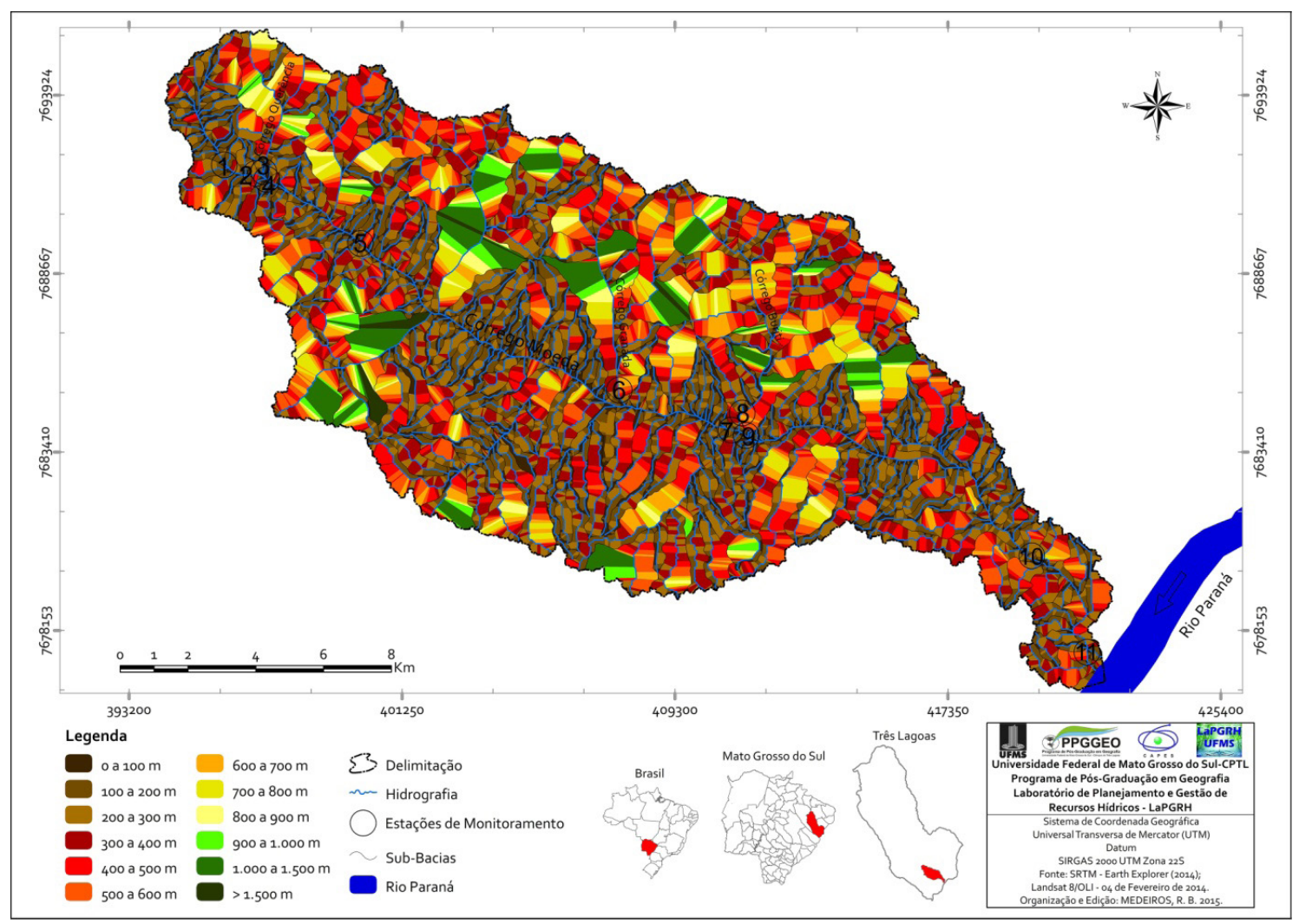

Tabela 5: Classes de dissecação horizontal, com suas respectivas áreas em $\mathbf{k m}^{2}$ e em \%, para a BHCM, Três Lagoas/MS.

\begin{tabular}{l|c|c}
\multicolumn{1}{c|}{$\begin{array}{c}\text { Classes de Dissecação Horizontal } \\
\text { (metros) }\end{array}$} & Área $\left(\mathbf{K m}^{\mathbf{2}}\right)$ & Área (\%) \\
\hline 0,00 a 100,00 & 23,27 & 9,40 \\
\hline 100,01 a 200,00 & 46,77 & 18,89 \\
\hline 200,01 a 300,00 & 43,03 & 17,37 \\
\hline 300,01 a 400,00 & 32,15 & 12,98 \\
\hline 400,01 a 500,00 & 27,33 & 11,04 \\
\hline 500,01 a 600,00 & 21,35 & 8,62 \\
\hline 600,01 a 700,00 & 16,08 & 6,49 \\
\hline 700,01 a 800,00 & 12,72 & 5,14 \\
\hline 800,01 a 900,00 & 6,47 & 2,61 \\
\hline 900,01 a $1.000,00$ & 5,53 & 2,24 \\
\hline $1.000,01$ a $1.500,00$ & 11,46 & 4,63 \\
\hline$>1.500,00$ & 1,43 & 0,59 \\
\hline
\end{tabular}


Correlacionando o mapa de Dissecação Horizontal com os dados quantificados de suas classes, foi possível identificar um predomínio da classe 100 a 200m, sendo característico em grande maioria das sub-bacias encontradas na BHCM e classificadas como Peso 11 de potencial erosivo.

A classe de 0 a $100 \mathrm{~m}$ abrangeu $23,27 \mathrm{~km}^{2}$, ou 9,40\%. Estas áreas são apontadas como Peso 12 de potencial erosivo, pois sua rampa é estreita, canais mais encaixados e retilíneos, portanto, o escoamento superficial tende a ser mais elevado, potencializando os processos erosivos e, consequentemente, causando uma vulnerabilidade neste ambiente.

Outra classe que abrangeu grandes áreas da BHCM é de 200 a 300m, apontando um total de $43,03 \mathrm{~km}^{2}$, ou 17,37\%, sendo áreas classificadas com Peso 10 de potencial erosivo, sendo representativo na visualização do mapa de Dissecação Horizontal.

A rampa mais suave foi classificada pela classe $>1.500 \mathrm{~m}$. Foi encontrada, sobretudo, nos maiores afluentes do médio curso do córrego Moeda, alcançando um total de apenas $1,43 \mathrm{~km}^{2}$, ou $0,59 \%$, não sendo representativo em termos quantitativos na BHCM. Estas áreas podem ser analisadas como áreas de várzea ou locais com desnível suave, portanto, foi classificado como Peso 1.

Na elaboração do mapa de Dissecação Vertical da BHCM, ficaram evidenciadas doze classes, levando-se em conta que os pesos oferecidos são opostos aos dados na Dissecação Horizontal, ou seja, partem do Peso 1 ou Peso 12. Onde as maiores dissecações verticais (em altitude) apresentam uma rampa mais ondulada, maior velocidade no fluxo d'água e, consequentemente, maior poder erosivo.

As classes partiram da metodologia de Spiridonov (1981), onde as classes têm início na foz do canal passando até a intersecção do canal fluvial até as curvas de nível de todos os patamares altimétricos da sub-bacia (curvas de nível de 10 em 10 metros).

Com a Figura 6 é possível a identificação das classes, e na Tabela 6 são representados os valores obtidos em $\mathrm{km}^{2}$ e porcentagem para cada classe na BHCM. 
Figura 6: Mapa de dissecação vertical da BHCM, Três Lagoas/MS.

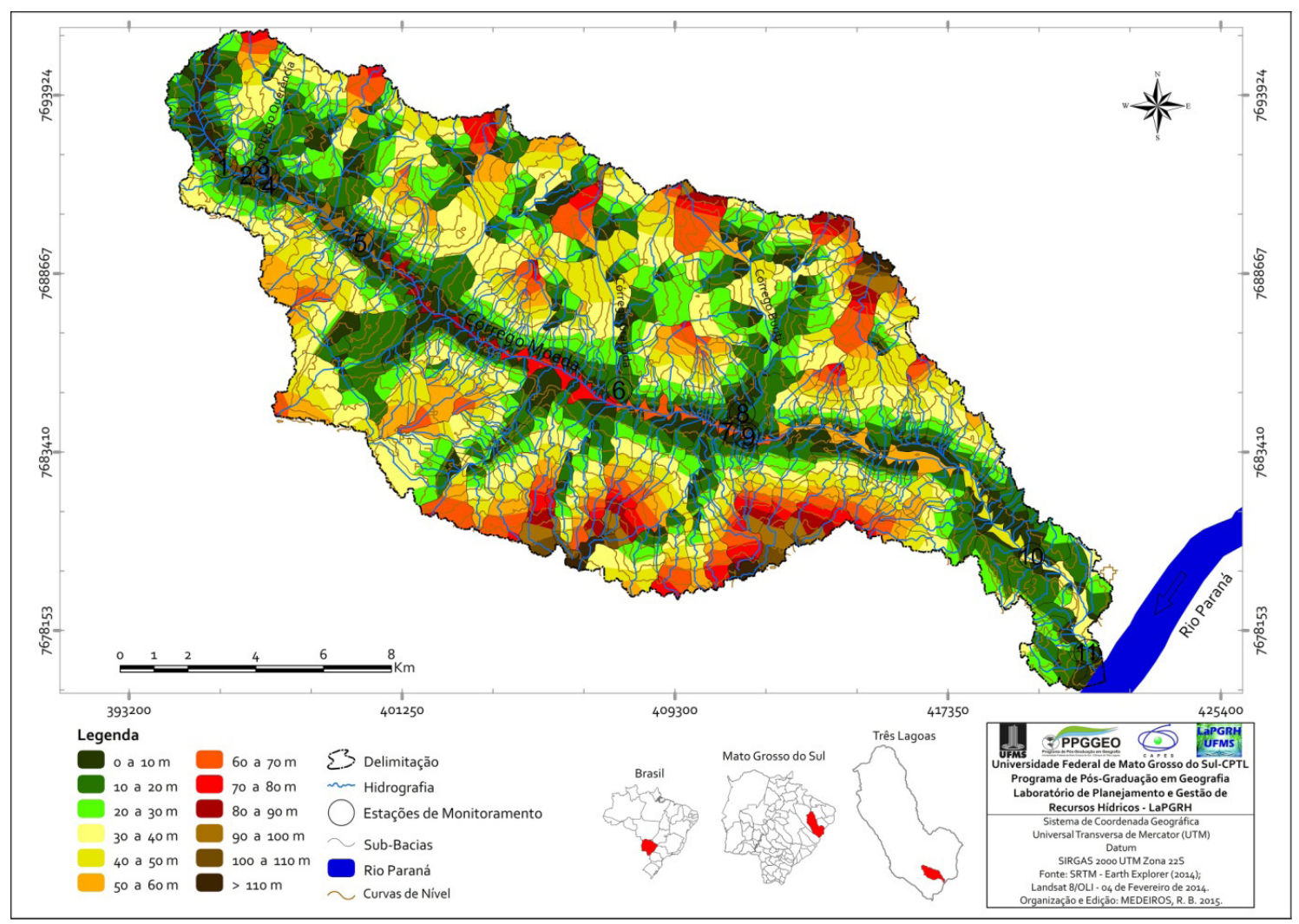

Tabela 6: Classes de dissecação vertical com suas respectivas áreas em $\mathbf{k m}^{2}$ e $\%$ na BHCM.

\begin{tabular}{c|cc} 
Classes de Dissecação Vertical (metros) & Área $\left(\mathbf{K m}^{\mathbf{2}}\right)$ & Área (\%) \\
\hline 0,00 a 10,00 & 25,63 & 10,35 \\
\hline 10,01 a 20,00 & 47,65 & 19,22 \\
\hline 20,01 a 30,00 & 40,15 & 16,20 \\
\hline 30,01 a 40,00 & 46,00 & 18,57 \\
\hline 40,01 a 50,00 & 32,08 & 12,96 \\
\hline 50,01 a 60,00 & 21,03 & 8,49 \\
\hline 60,01 a 70,00 & 15,33 & 6,19 \\
\hline 70,01 a 80,00 & 7,50 & 3,06 \\
\hline 80,01 a 90,00 & 4,30 & 1,74 \\
\hline 90,01 a 100,00 & 3,73 & 1,51 \\
\hline 100,01 a 110,00 & 1,98 & 0,80 \\
\hline$>110,00$ & 2,26 & 0,91 \\
\hline
\end{tabular}


É notável a presença da primeira classe ( 0 a 10m) nas proximidades da foz de todos os recursos hídricos da BHCM até a intersecção do canal fluvial com a curva de nível. Com isto muitas áreas foram abrangidas, contudo, por ser a primeira classe, está situada em limites de menor extensão, fazendo com que não apresentasse uma área de maioria considerável, alcançando $25,63 \mathrm{~km}^{2}$.

A segunda classe (10 a 20m) abrangeu a intersecção do canal fluvial com a primeira curva de nível até a segunda curva de nível, abrangendo áreas de maior extensão, pois apenas as sub-bacias menores não foram constatadas esta classe, alcançando um total de $47,65 \mathrm{~km}^{2}$, ou 19,22\%, figurando na classe de maior representatividade na BHCM.

Com relação à classe de 20 a 30m, foi extensa sua área de abrangência, chegando à $40,15 \mathrm{~km}^{2}$, ou 16,20\% do total da BHCM. Ao longo destas classes citadas, a dissecação ainda é fraca quanto à esculturação do relevo e transporte de sedimentos. O mesmo pode-se dizer da classe de 30 a 40m, pois não apresenta uma dissecação alta, sendo representada na $\mathrm{BHCM}$ por $46,00 \mathrm{~km}^{2}$ e $18,57 \%$.

A classe de 40 a $50 \mathrm{~m}$ apresentou 32,08km², ou 12,96\%. Esta classe mostra o início do declínio em área de extensão das classes, sobretudo, pois esta classe não é observada em todas as sub-bacias, levando-se em conta que todas as classes possuem um peso em relação à Mapa de Energia Potencial Erosiva do Relevo. Esta classe por sua vez, alcança um Peso 5.

A Dissecação Vertical que alcançou de 50 a 60 abrangeu uma área de $21,03 \mathrm{~km}^{2}$, ou $8,49 \%$ da área total, sendo representativo, principalmente, em sub-bacias mais alongadas, pois necessitam atravessar cinco patamares altimétricos.

A classe de 60 a $70 \mathrm{~m}$ apresenta-se em $15,34 \mathrm{~km}^{2}$, ou 6,19\%. Portanto, não é representativo em todas as sub-bacias, sendo apenas encontradas nas mais alongadas e nos principais afluentes da BHCM. O mesmo ocorre com a classe 70 a $80 \mathrm{~m}$, que alcançou $7,57 \mathrm{~km}^{2}$, ou 3,06\% do total da bacia hidrográfica.

A classe que representa 80 a 90m abrangeu apenas parte dos principais afluentes do médio curso da BHCM, não alcançando grandes valores de extensão $\left(4,30 \mathrm{~km}^{2}\right.$ ou 1,74\%). Nestes locais também foram encontradas a outra classe (90 a 100m) que alcançou $3,73 \mathrm{~km}^{2}$ e $1,51 \%$ da área total.

Localizada nestas áreas e característico das proximidades dos pontos 2, 3 e 4 de monitoramento das águas, a classe 100 a $110 \mathrm{~m}$ não alcançou grandes extensões, apenas $1,98 \mathrm{~km}^{2}$ e $0,80 \%$. A classe que menos foi representativa no geral foi de 100 a 110 metros, chegando à $1,98 \mathrm{~km}^{2}$, ou $0,80 \%$, mostrando que, mesmo obtendo um Peso 11 sobre o mapa de do 
Energia Potencial Erosiva do Relevo, acaba não influenciando de forma significativa nos seus valores, pois a extensão é pequena em relação ao total da BHCM. Por fim, o maior peso de energia potencial erosiva é dado na classe que abrange os patamares altimétricos maiores que $110 \mathrm{~m}$, abrangendo uma área de $2,26 \mathrm{~km}^{2}$ e $0,91 \%$.

Na elaboração da Energia Potencial Erosiva do Relevo da BHCM (Figura 7), foram constatadas doze classes, abrangendo dados de Declividade, Dissecação Horizontal e Dissecação Vertical. Estas informações foram correlacionadas e por meio dos pesos elaborados para cada classe e, de acordo com sua propensão a erosões, foi diagnosticada a capacidade que na BHCM poderá ocorrer de erosões, ou seja, seu potencial.

Na Tabela 7, foram quantificados em $\mathrm{km}^{2}$ e \% quanto cada classe ocupa na BHCM, visualizando as cores temáticas utilizadas, bem como sua nomenclatura e o peso que cada classe exerce sobre o mapa de Erosividade.

\section{Figura 7: Mapa de energia potencial erosiva do relevo da BHCM, Três Lagoas/MS.}

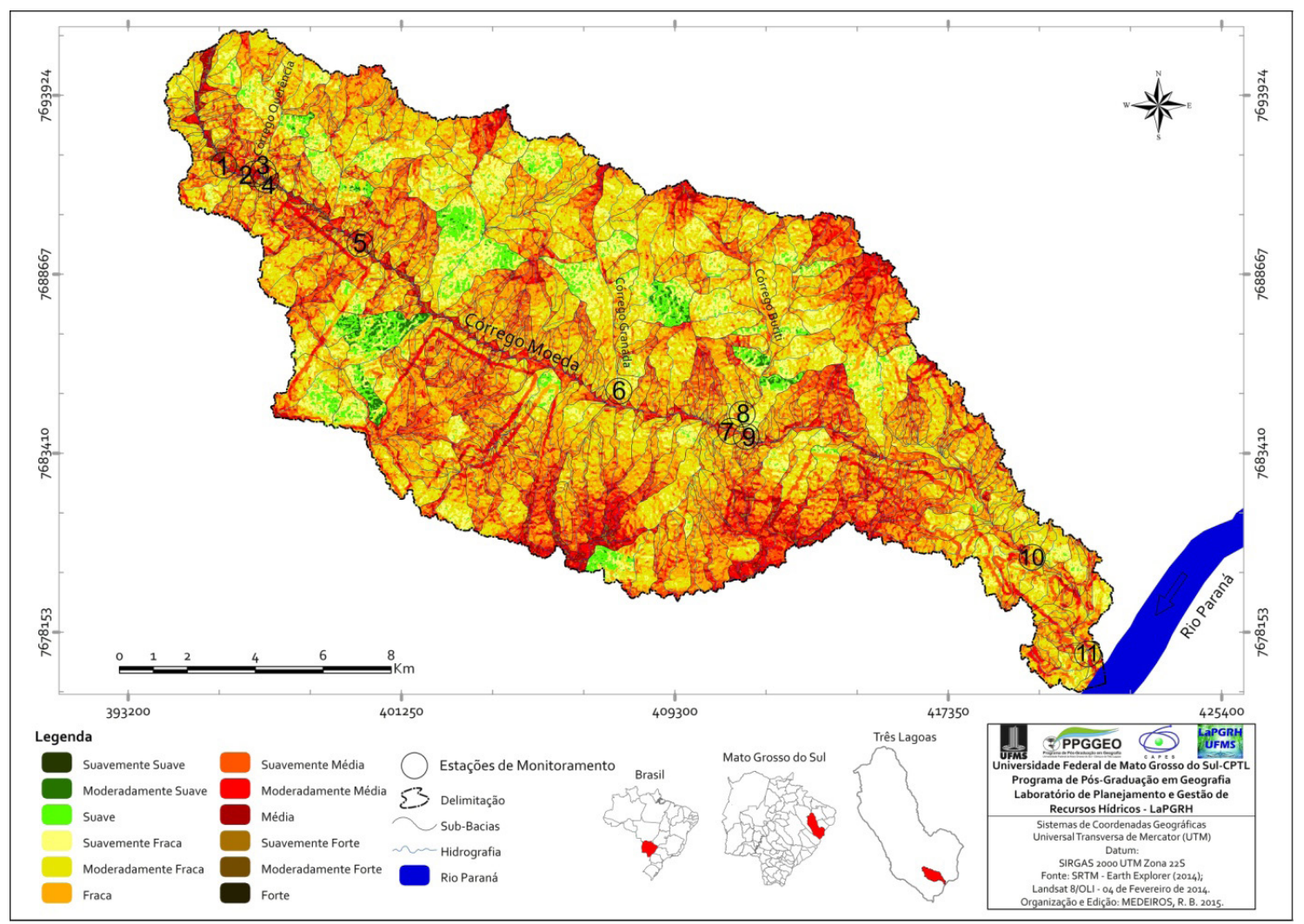


Tabela 7: Classificação da energia potencial erosiva com suas respectivas áreas em $\mathbf{k m}^{2}$ e \%, na BHCM.

\begin{tabular}{lcc}
\multicolumn{1}{c|}{ Classificação } & Área $\left(\mathbf{K m}^{\mathbf{2}}\right)$ & Área (\%) \\
\hline Suavemente Suave & 0,13 & 0,05 \\
\hline Moderadamente Suave & 1,65 & 0,67 \\
\hline Suave & 9,54 & 3,85 \\
\hline Suavemente Fraca & 28,36 & 11,45 \\
\hline Moderadamente Fraca & 63,57 & 25,67 \\
\hline Fraca & 72,46 & 29,26 \\
\hline Suavemente Média & 45,34 & 18,31 \\
\hline Moderadamente Média & 19,55 & 7,89 \\
\hline Média & 5,62 & 2,27 \\
\hline Suavemente Forte & 1,11 & 0,45 \\
\hline Moderadamente Forte & 0,16 & 0,07 \\
\hline Forte & 0,15 & 0,06 \\
\hline
\end{tabular}

Com a elaboração do mapa de Energia Potencial Erosiva do Relevo é possível afirmar que a classe de maior extensão encontrada na BHCM é Fraca, alcançando um total de $72,46 \mathrm{~km}^{2}$, ou $29,26 \%$, sendo encontrada ao longo de toda a bacia hidrográfica. Outra classe que abrangeu grandes áreas é a Moderadamente Fraca com 63,57 km², ou 25,67\% do total da BHCM. Entretanto, apesar de ser considerada "Fraca”, este grau de energia potencial, quando aliada a outros fatores como a perda de sedimentos, escoamento superficial, entre outros elementos tende a se tornar mais grave, necessitando de controle e proteção, visando à minimização dos impactos que podem vir a ocorrer nestas áreas que abrangeram grande parte da BHCM.

A pior classe de Energia Potencial Erosiva do Relevo foi encontrada nas proximidades do ponto 1 , compreendendo apenas $0,15 \mathrm{~km}^{2}$. É uma área com relativa declividade ( 9 a $12 \%$ ) e abrange a Dissecação Horizontal de 0 a 100m e Dissecação Vertical de >110m. Dessa forma, na interpolação dos dados, acabou sendo classificada como Forte.

A classificação Moderadamente Forte foi encontrada apenas ao longo das proximidades das margens do Córrego Moeda, em seu alto e alto/médio curso, e também ao sul do ponto 6, próximo ao limite da BHCM. Devido a isto, abrangeu reduzida extensão $\left(0,16 \mathrm{~km}^{2}\right)$.

A classe Suavemente Média abrangeu relativa extensão na BHCM, alcançando $45,34 \mathrm{~km}^{2}$, ou $18,31 \%$, abrangendo locais ao longo de toda a bacia hidrográfica, especialmente nas áreas com declividade elevada, que necessitam de uma conservação dos solos e limitam sua utilização. 
A Figura 8 mostra uma área classificada como Média, que se localiza próximo ao ponto 11 de monitoramento das águas superficiais. Esta classe compreendeu $5,62 \mathrm{~km}^{2}$, ou $2,27 \%$ do total da BHCM.

Figura 8: Baixo curso da BHCM, classificada como energia potencial erosiva do relevo média.

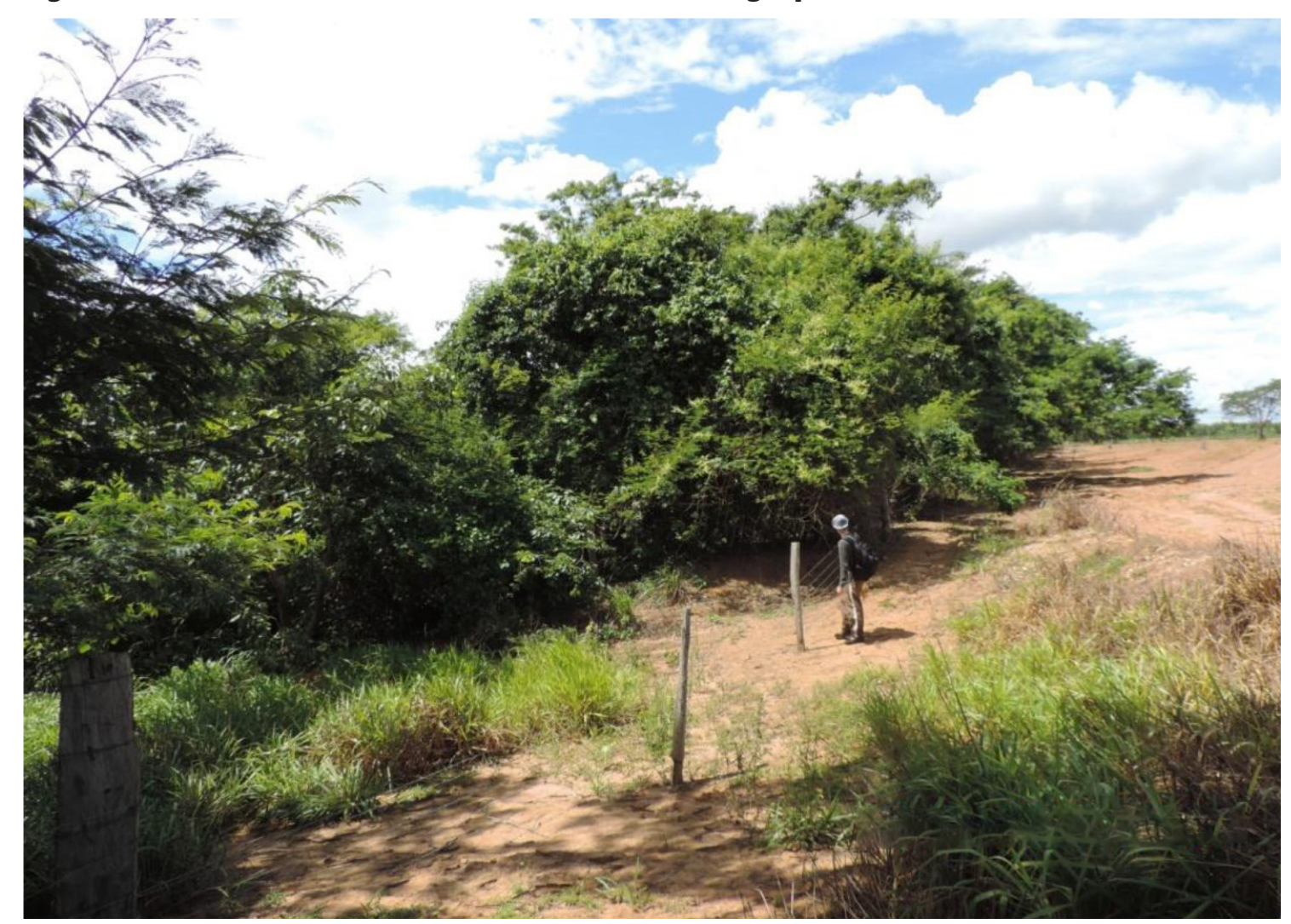

$\mathrm{Na}$ BHCM predomina um potencial erosivo de Suavemente Suave a Forte, não apresentando apenas a Classe Muito Forte, mostrando-se uma pesquisa importante, pois não visa apenas à análise do potencial erosivo da BHCM, mas também busca correlacionar estas variáveis com diversas outras (precipitações, perda de solo e quantidade das águas), buscando analisar de forma mais definida e concreta a situação que se encontra a área de estudo, e quais as maneiras de manter este ambiente em equilíbrio diante dos vários elementos que se compõe e se interagem dentro deste sistema.

No mapeamento da Energia Erosiva do Transporte de Sedimentos em Suspensão da BHCM, é possível identificar à carga real do carreamento de sedimentos em suspensão, provocadas pelo turbilhonamento das águas ao longo das vertentes e que alcançam o canal fluvial, utilizando-se de dados de velocidade das águas superficiais, vazão e transporte de sedimentos em suspensão nos canais fluviais, ao longo dos onze pontos de coletas das águas superficiais, sendo que cada ponto analisado possui uma área de drenagem (sub-ba- 
cia). Por meio dos valores obtidos em cada ponto, foi elaborado pesos em cada sub-bacia, analisando sua influência sobre o mapa de Erosividade da BHCM.

As análises da velocidade de fluxo e vazão podem indicar os locais, ao longo da $\mathrm{BH}$ $\mathrm{CM}$, que vem ocorrendo processos erosivos e de deposição de sedimentos. Estes fatores estão ligados diretamente à rugosidade do canal e provocam ao ambiente algumas perturbações, pois influencia na quantidade e qualidade das águas.

As áreas dos canais fluviais obtiveram grandes variações, como pode ser visualizado na Figura 9, sendo apontado o verão com as maiores áreas na média geral das estações, com o ponto 11 obtendo as maiores áreas dentre todos os pontos de monitoramento analisados, com exceção do inverno, ocorrendo a maior área no ponto 7.

Figura 9: Variação das áreas do canal fluvial nos pontos de monitoramento na BHCM, em 2014.

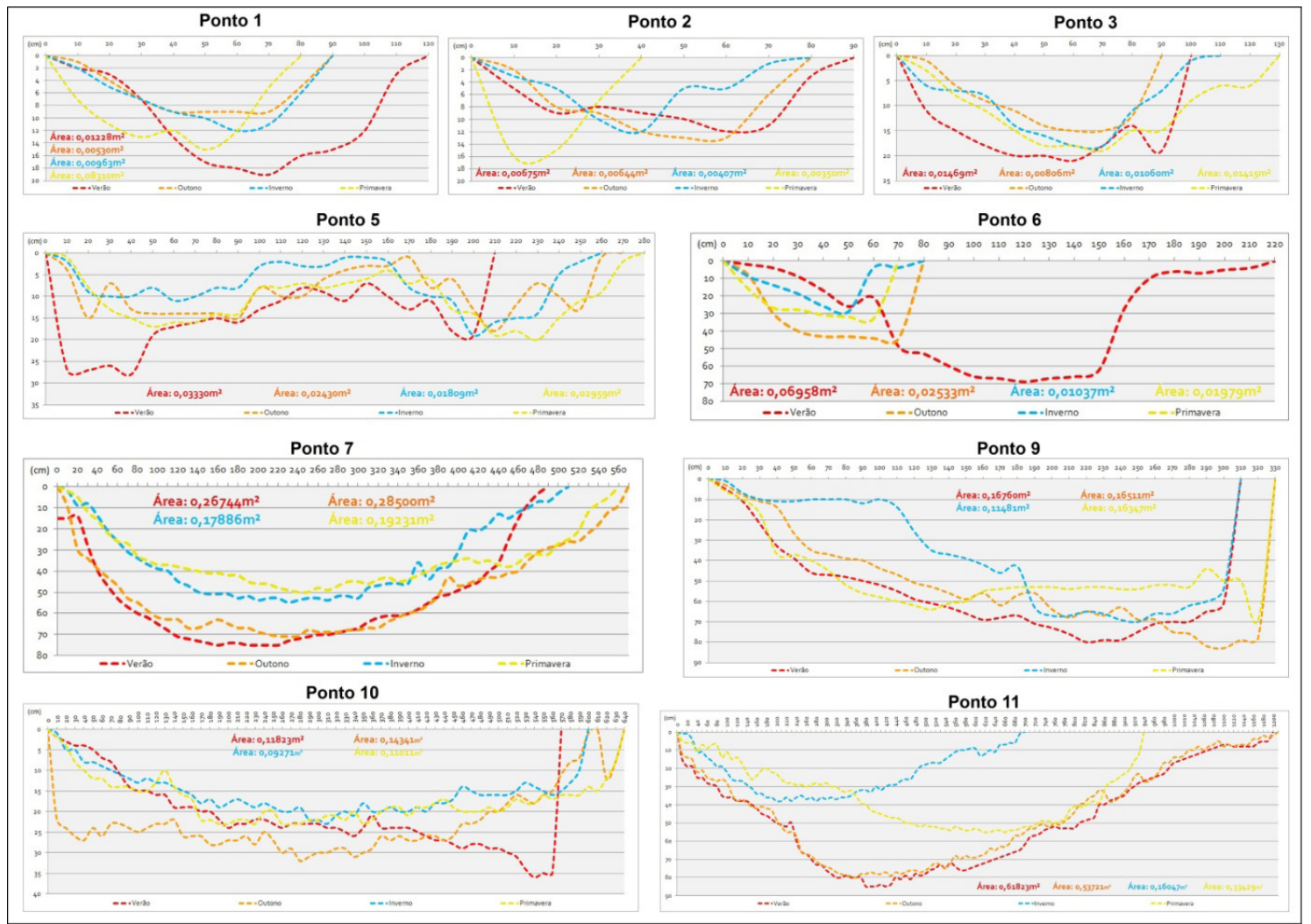

Com exceção do inverno, onde a maior vazão foi no ponto 9, as mais elevadas foram mensuradas também no verão, onde novamente o ponto 11 obteve números mais expressivos, devido, principalmente estar localizado no baixo curso do córrego Moeda, local que abrange maior área drenada da bacia. 
As reduções de vazão de montante a jusante, nos pontos 6 e 9, expressam a perda de água devido ao ambiente geológico/geomorfológico, que propicia maior infiltração e perda por evapotranspiração. Já o ponto 8 refere-se ao afluente da margem esquerda o córrego Buriti, que é intermitente. Vale ainda salientar que o ponto 5, que marca a passagem do alto para o médio curso, encontra-se na área de vegetação riparia de galeria mais densa e preservada da bacia, o que auxilia na sua boa vazão.

Possuindo interferência direta da vazão e velocidade de fluxo das águas, o transporte de sedimentos em suspensão ao longo das estações do ano de 2014, demonstraram a relativa quantidade de sedimentos no ponto 5, alcançando o máximo de 16,98 toneladas na primavera. Esta área apresenta como característica uma ponte, poucos metros à sua montante, que interfere de forma significativa no transporte, pois as chuvas que ocorreram neste ano, fizeram com que ocorresse um desmoronamento de sua encosta, formando pequena queda d'água que altera não só o transporte de sedimentos em suspensão, como também a vazão e velocidade de fluxo das águas superficiais, Figura 10.

\section{Figura 10: Variação do Transporte de Sedimentos em Suspensão e Velocidade de Fluxo e Vazão no ano de 2014 na BHCM.}

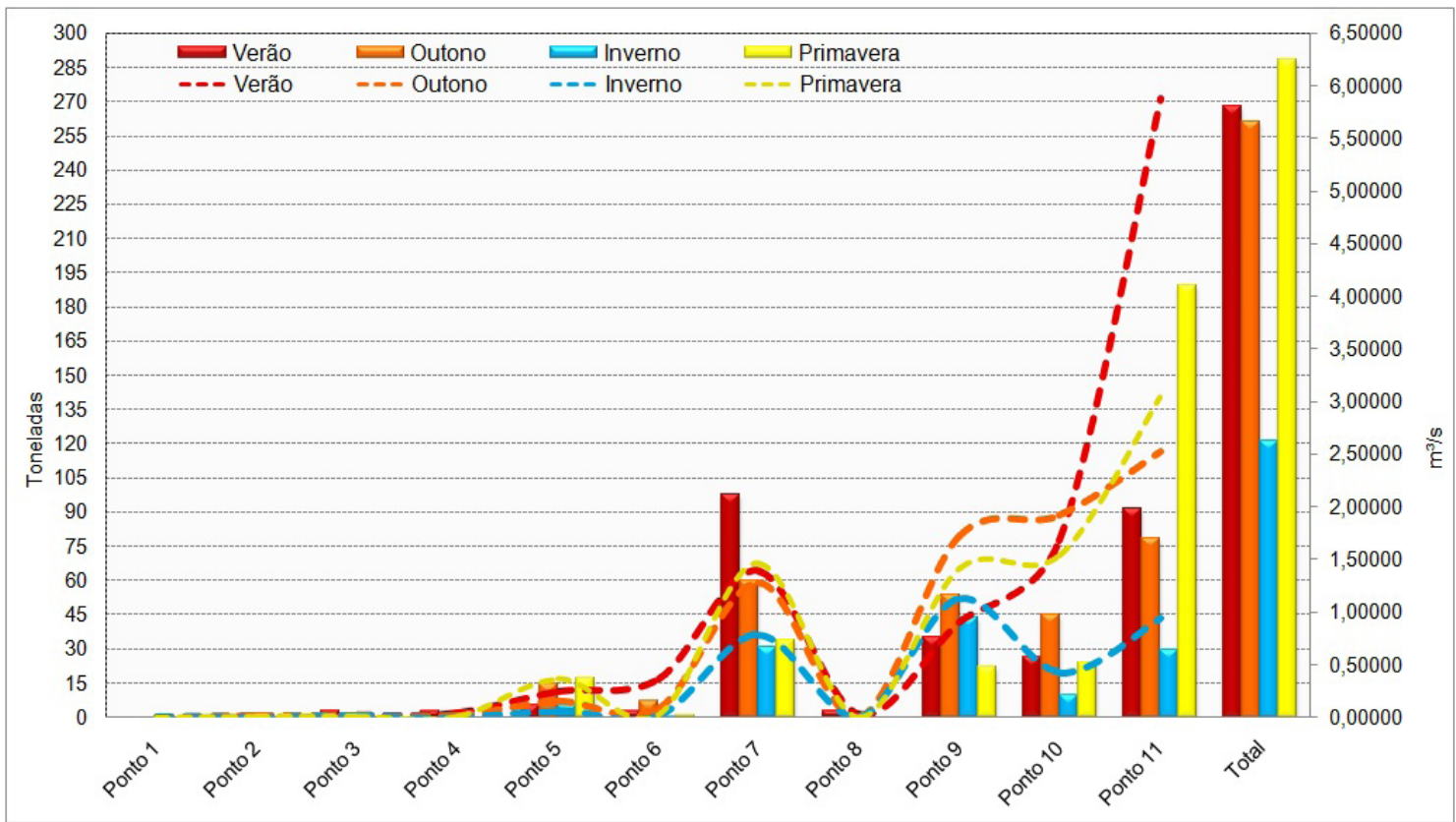

No ponto 7 ocorre o transporte de grande quantidade de sedimentos, como também ocorre um processo deposicional, poucos metros antes da ramificação do córrego Moeda, em três pequenos canais fluviais, devido a uma ruptura no relevo. Outro importante fator que eleva o transporte de sedimentos neste ponto é a falta de mata ciliar em sua margem direita, caracterizado como um local que servia de entrada de gado co- 
mo bebedouro. Com isto o transporte neste ponto atingiu o número máximo de 97,32 toneladas no verão.

Outro que merece destaque é o ponto 9, pois possui mata ciliar, contudo devido sua alta velocidade e por se encontrar encaixado com barranco nas duas margens, ocasiona no assoreamento destes barrancos e seu consecutivo aumento na quantidade de sedimentos em suspensão, atingindo seu pico no outono, com 53,66683 toneladas

O ponto 10 possui alta velocidade e relativa vazão. Contudo o fundo do canal é formado por cascalhos, o que diminui a quantidade de sedimentos em suspensão, não apontando uma grande quantidade no transporte se fosse levar em conta sua velocidade e vazão. É possível apontar, neste ponto, que poucos metros à sua montante há uma ponte que serve para passagem de caminhões carregados de eucalipto da Fibria MS Celulose Ltda., sendo apontando também como um fator prejudicial, bem como a falta de mata ciliar em toda a margem esquerda do ponto 10 .

O ponto 11 apresentou o maior transporte de sedimentos em suspensão entre todos os pontos durante 2014. Com 189,23 toneladas na primavera, esta área é característica por possuir mata ciliar em sua margem direita e, com a chegada das precipitações, toda sua margem esquerda, que não possui mata ciliar, fica com solo hidromórfico, aumentando a turbidez das águas e alterando o transporte de sedimentos em suspensão devido à decomposição de matéria orgânica presente neste “brejo".

A BHCM obteve as maiores quantidades de sedimentos na primavera. Este acontecimento pode ser explicado devido ao solo apresentar certo ressecamento, tanto devido à precipitação quanto à temperatura mais reduzida do inverno. Com isto o aumento das precipitações da primavera ocasiona um escoamento superficial mais elevado e acaba carreando sedimentos até os recursos hídricos.

Durante o verão, que neste ano foi atípico, com poucas chuvas em relação à prévia climatológica, fez com que não ocorressem grandes variações de transporte de sedimentos em suspensão, chegando à 267,82 toneladas. Quando este valor é comparado com o de outono, que obteve precipitações próximas às prévias climatológicas, observa-se que houve, no transporte de sedimentos em suspensão, uma pequena queda, mas que manteve próximos os valores.

Com relação ao inverno, também apresentou situações atípicas neste ano de 2014, com precipitações muito superiores em comparação com a prévia climatológica. Entretanto, obteve-se pouco transporte de sedimentos em suspensão, alcançando 120,97 toneladas, o menor valor entre todas as estações analisadas.

$$
\text { ladas, o menor valor entre todas as estações analisadas. }
$$


Todas estas informações correspondem ao reflexo da ação erosiva sobre as vertentes da BHCM. Juntamente com a interação com outras variáveis, acaba alterando todo o comportamento hidrossedimentológico dos canais fluviais desta bacia hidrográfica, evidenciando assim, a Erosividade da BHCM.

Esta análise de mostra necessária, buscando espacializar, ao longo da BHCM, os dados obtidos de transporte de sedimentos. Com isso, o mapa de energia erosiva de transporte de sedimentos em suspensão, auxilia no apontamento dos locais mais propensos às erosões, seja devido seu relevo, bem como, a pluviosidade que foi mais elevada em determinadas épocas do ano de análise, seguindo a metodologia de Pinto et. al. (2010), Tabela 8 e Figura 11.

Tabela 8: Classes de energia erosiva de transporte de sedimentos em suspensão no de 2014, na BHCM, Três Lagoas/MS.

\begin{tabular}{|c|c|c|c|c|c|c|c|}
\hline $\begin{array}{l}\text { Classes e } \\
\text { Pesos sobre } \\
\text { o mapa de } \\
\text { Erosividade }\end{array}$ & $\begin{array}{c}\text { Transporte de } \\
\text { Sedimentos em } \\
\text { Suspensão (g/ } \\
\left.\mathbf{m}^{3} / \mathbf{s}\right)\end{array}$ & $\begin{array}{c}\text { Pontos de } \\
\text { Monitora- } \\
\text { mento }\end{array}$ & $\begin{array}{l}\text { Verão } \\
2014\end{array}$ & $\begin{array}{c}\text { Outono } \\
2014\end{array}$ & $\begin{array}{c}\text { Inverno } \\
2014\end{array}$ & $\begin{array}{c}\text { Primavera } \\
2014\end{array}$ & Média \\
\hline 1 & 0,00 a 1,00 & Ponto 1 & * & * & * & * & -- \\
\hline 2 & 1,01 a 2,00 & Ponto 2 & 1 & 1 & 1 & 1 & 1 \\
\hline 3 & 2,01 a 4,00 & Ponto 3 & 1 & 1 & 1 & 1 & 1 \\
\hline 4 & 4,01 a 6,00 & Ponto 4 & 1 & 1 & 1 & 1 & 1 \\
\hline 5 & 6,01 a 10,00 & Ponto 5 & 1 & 2 & 1 & 3 & 2 \\
\hline 6 & 10,01 a 15,00 & Ponto 6 & 1 & 1 & 1 & 1 & 1 \\
\hline 7 & 15,01 a 20,00 & Ponto 7 & 6 & 5 & 3 & 4 & 5 \\
\hline 8 & 20,01 a 25,00 & Ponto 8 & 1 & ** & ** & ** & 1 \\
\hline 9 & 25,01 a 30,00 & Ponto 9 & 4 & 5 & 5 & 3 & 4 \\
\hline 10 & 30,01 a 35,00 & Ponto 10 & 3 & 4 & 2 & 3 & 3 \\
\hline 11 & 35,01 a 40,00 & Ponto 11 & 6 & 6 & 3 & 8 & 6 \\
\hline 12 & $>40,01$ & & & & & & \\
\hline Média & & & 2,50 & 2,89 & 2,00 & 2,78 & 2,50 \\
\hline
\end{tabular}

${ }^{*}$ Açude, ambiente lêntico. ${ }^{* *}$ Canal Fluvial Seco. 
Figura 11: Mapa de energia erosiva do transporte de sedimentos em suspensão por estação e a média, em 2014 na BHCM.

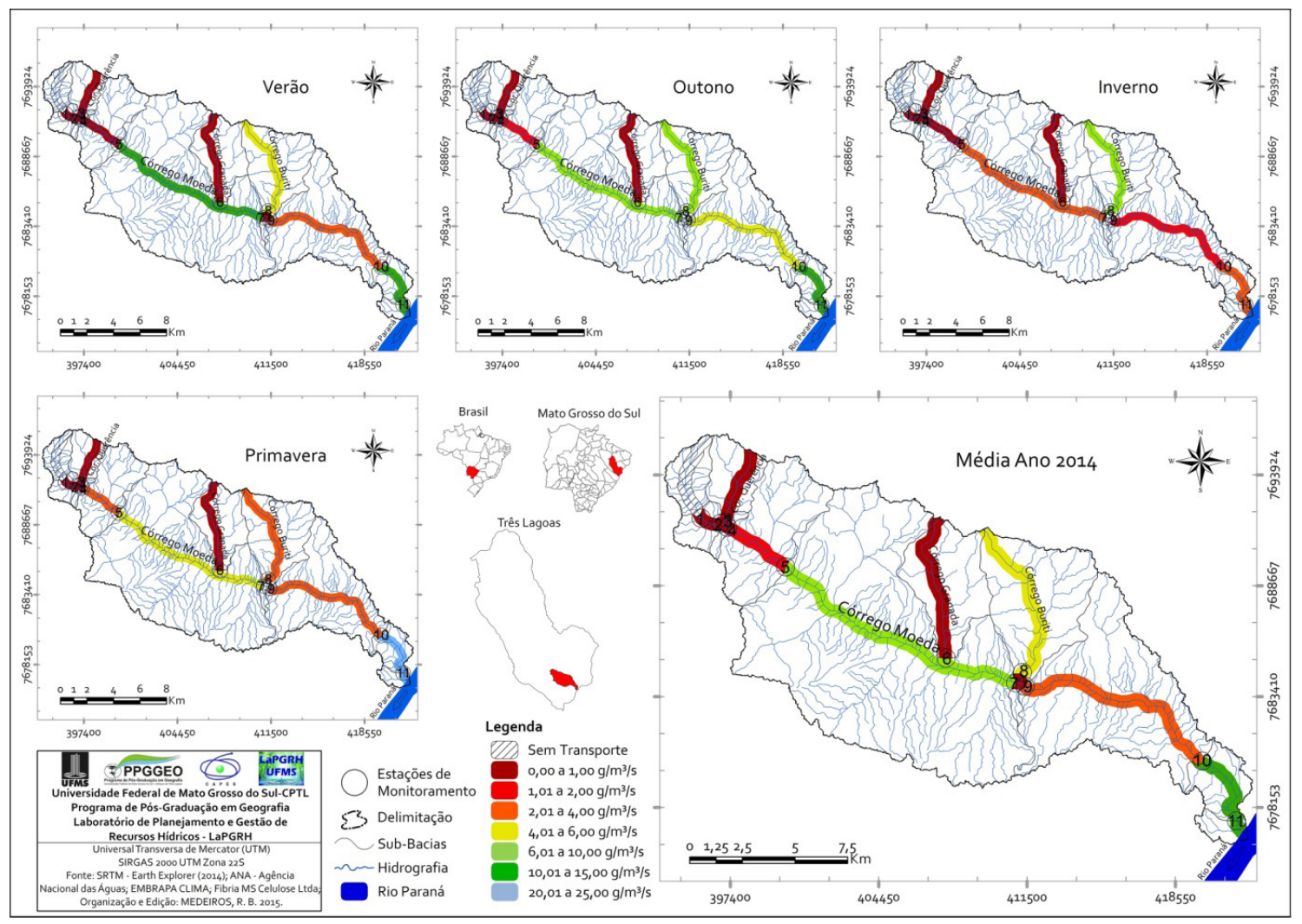

Os pontos analisados não representaram grandes valores de energia erosiva de transporte de sedimentos em suspensão. Os pontos 1, 2, 3 e 6 apresentaram em todas as estações valores referentes à Classe 1 . Com isto sua média geral das estações ficou enquadrada nesta classe, que apresenta valores de 1,01 a $2,00 \mathrm{~g} / \mathrm{m}^{3} / \mathrm{s}$.

O ponto 5 mostrou um relativo aumento em seus valores, principalmente no outono e primavera. Esta última podendo ser explicada pelo aumento na quantidade de chuvas nesta estação e por ser um ponto que está localizado à jusante de uma ponte de captação de água da Fibria MS Celulose Ltda., que acabou desmoronando, podendo ser um agravante que eleve a quantidade de sedimentos em suspensão e cause alterações na velocidade de fluxo e vazão das águas superficiais, como mostra a Figura 12 e 13. 


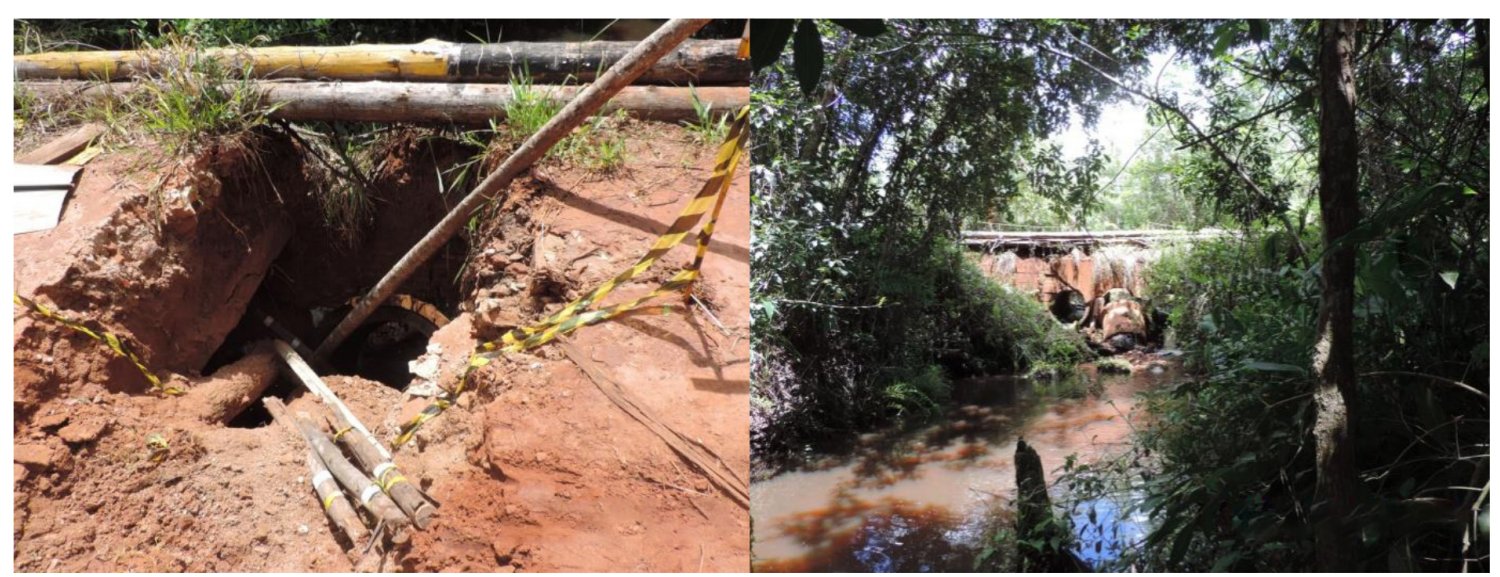

Figura 12: Ponto 5, desmoronamento visto da ponte.

Figura 13: Ponto 5, desmoronamento da Ponte, a montante do ponto.

O ponto 7 merece destaque nesta análise devido, principalmente, à quantidade de sedimentos em suspensão que é carreado nesta área que, somado à alta velocidade de fluxo e vazão das águas, eleva sua energia erosiva do transporte de sedimentos em suspensão na Bacia. Foi apontado que durante as estações do verão, outono, inverno e primavera sua energia erosiva de transporte de sedimentos em suspensão alcançou a Classe 6, 5, 3 e 4 respectivamente, constatando, assim, uma média na Classe 5 , ou seja de 10,01 a 15,00g/m $/ \mathrm{m}^{3} \mathrm{~s}$.

O ponto 7 sofre forte influência da considerável área em sua margem direita, destinada à pastagem sem qualquer tipo de manejo ou curvas de nível, apresentando pastagens batidas e ralas. Desta forma as chuvas de outubro, novembro e dezembro ocasionaram um grande poder de desagregação e carreamento de sedimentos.

O ponto 8 foi caracterizado por se encontrar seco, com exceção do verão, onde foi enquadrado na Classe 1, obtendo a média nesta mesma classe. Já o ponto 9 possui altas velocidades auxiliando no aumento da competência, apontando a Classe 4 (verão), Classe 5 (outono), Classe 5 (Inverno) e Classe 3 (primavera). Este ponto é diferenciado por se encontrar encaixo, onde as duas margens possuem barrancos que as altas velocidades acabam assoreando, levando sedimentos nos recursos hídricos e, consequentemente, eleva sua energia erosiva de transporte de sedimentos em suspensão, chegando à Classe 4 de média com 25,01 a $30,00 \mathrm{~g} / \mathrm{m}^{3} / \mathrm{s}$.

O ponto 10, apesar de sua alta velocidade, está localizado em uma área com grande quantidade de cascalho em seu leito, o que reduz o transporte fluvial. Mesmo com estas variáveis o transporte alcançou a Classe 3, obtendo, ao longo das estações do ano, variações reduzidas em seus valores, como inverno apontado com a menor classificação (Classe 
2) e o outono, que alcançou a Classe 4. Outro fator que eleva sua energia erosiva de transporte de sedimentos em suspensão é a falta de mata ciliar em toda sua margem direita, bem como a proximidade com uma ponte que serve de passagem para caminhões da Fibria MS Celulose Ltda.

Por fim, o ponto 11 apresenta elevada vazão e uma relativa velocidade de fluxo das águas se comparada com os demais pontos. Este local apresenta a maior energia erosiva de transporte de sedimentos em suspensão da BHCM, apontando para a média na Classe 6. O inverno apresentou a menor classificação e na primavera foi constatada a maior. Este fato ocorreu devido principalmente à vazão, mas também devido à existência de uma área de "brejo" na margem esquerda do canal, que eleva sua turbidez e aumenta a quantidade de sedimentos em suspensão.

Diante dos dados obtidos, todas estas variáveis, necessárias para a elaboração da Erosividade da BHCM, fazem parte do conjunto de informações, onde sua correlação ocasiona uma análise mais detalhada e verídica da área de estudo, apontando as áreas de maior suscetibilidade erosiva, auxiliando em futuras ações de proteção e conservação deste ambiente natural.

Estes dados de Erosividade são estacionais, podendo, assim, visualizar as implicações que as precipitações acarretam sobre o relevo e sua conseqüente influência sobre a vazão, velocidade das águas e transporte de sedimentos em suspensão.

Com isso, a evolução da Erosividade ao longo de 2014, mostrou alguns fatores de influência, como estações chuvosas e secas e a energia erosiva do transporte de sedimentos em suspensão. As variações destes elementos proporcionaram uma modificação nas classes de maior abrangência de Erosividade, Figura 14 e 15. 
Figura 14: Mapa de Erosividade média da BHCM, Três Lagoas/MS, em 2014.

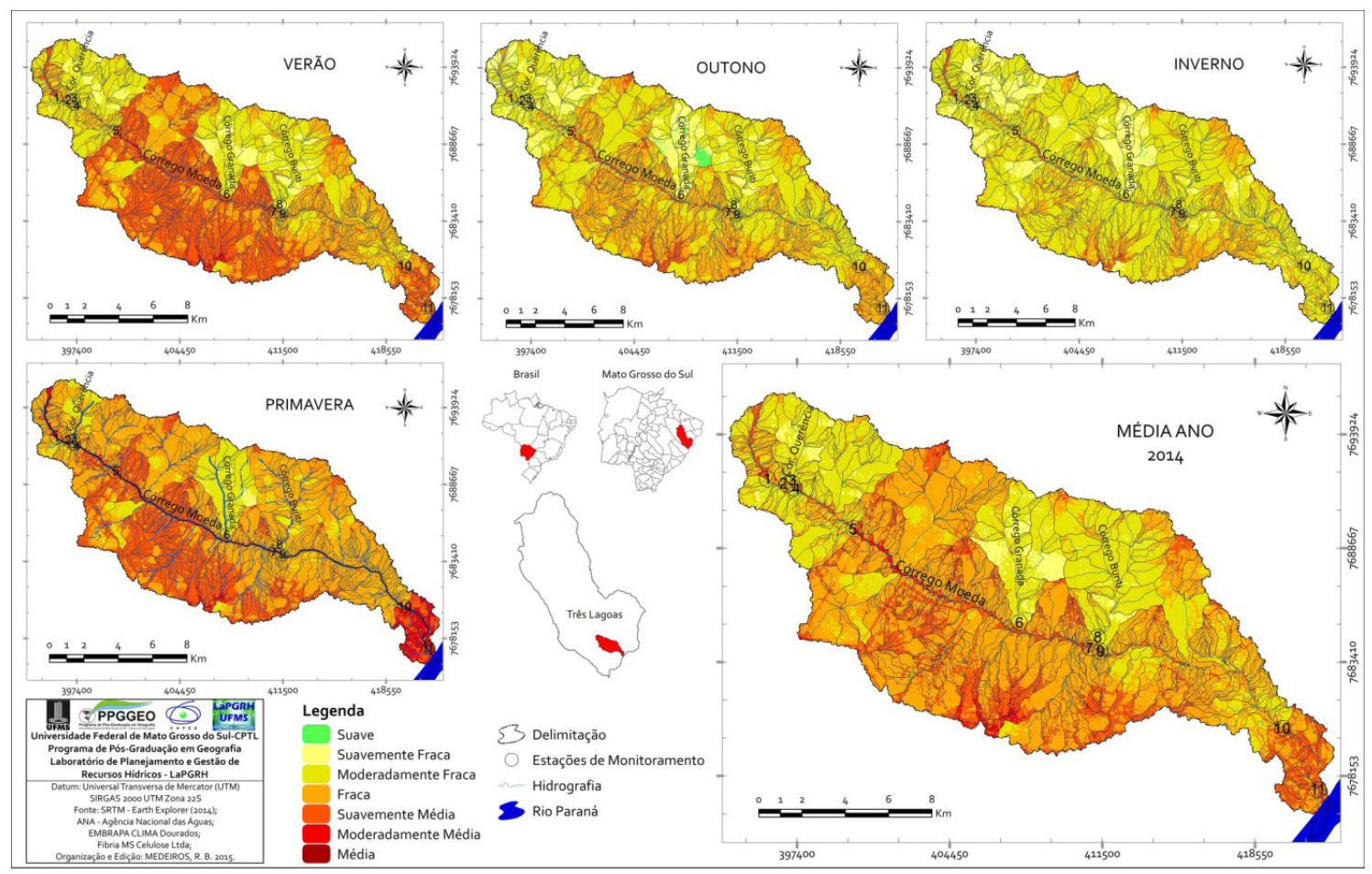

Figura 15: Evolução da Erosividade ao longo das estações do ano de 2014, na BHCM, Três Lagoas, MS.

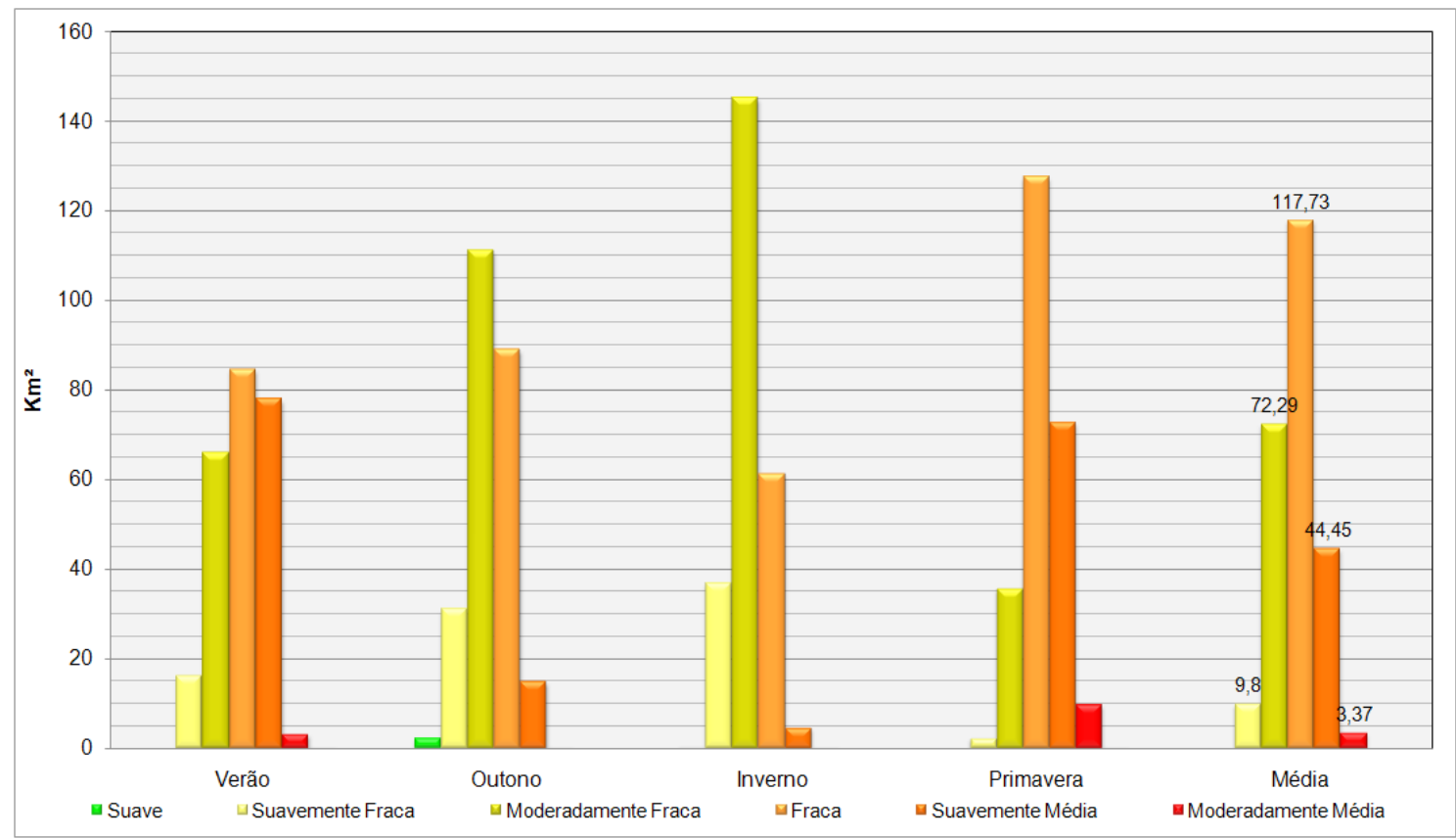


Na visualização da Erosividade é possível a identificação dos declives mais acentuados, e a relação das sub-bacias, pois os córregos Querência, Granada e Buriti apresentam Erosividade reduzida. Entretanto, as sub-bacias do ponto 1, 7, 9, 10 e 11 apresentam altas Erosividades, sobretudo pela alta na energia erosiva do transporte de sedimentos em suspensão.

Com a evolução é possível identificar a influência das precipitações, principalmente pelo fato de que nas estações secas a classe de Erosividade de maior abrangência foi a Moderadamente Fraca, com o aumento das precipitações no verão e primavera. A classe Fraca apontou as maiores áreas.

A fazenda Querência foi um local que apresentou alta Erosividade ao longo do ano de 2014 devido a alteração no relevo para que possa haver a retenção da água, para a implantação da represa (Figura 16). Com isto, elevou-se a declividade do local que, mesmo sendo uma área reduzida, provoca um escoamento elevado, podendo ocasionar erosões, principalmente, pelo fato de não possuir uma vegetação consistente de raízes profundas que retenham o solo e proteja-o contra possíveis deslizamentos de terra.

Outro local que chamou a atenção pelas feições erosivas existentes, mesmo sendo classificado por Erosividade Fraca na maioria das estações, foi nas margens da rodovia MS-395, sendo possível constatar algumas erosões avançando em direção à rodovia, sendo possível visualizar a perda de solos, fator este prejudicado pela falta de manejo em seu entorno.

Estas áreas foram classificadas como declive de aproximadamente 5\%, e que possui rampas alongadas que vão até o córrego Moeda, elevando seu escoamento superficial e que, somados à rodovia, acabam intensificando estas feições erosivas, como pode ser visualizado na Figura 17.

\section{Figura 16: Vertente íngreme do aterro da Figura 17: Feições erosivas às margens da barragem no córrego Querencia. rodovia MS-395.}

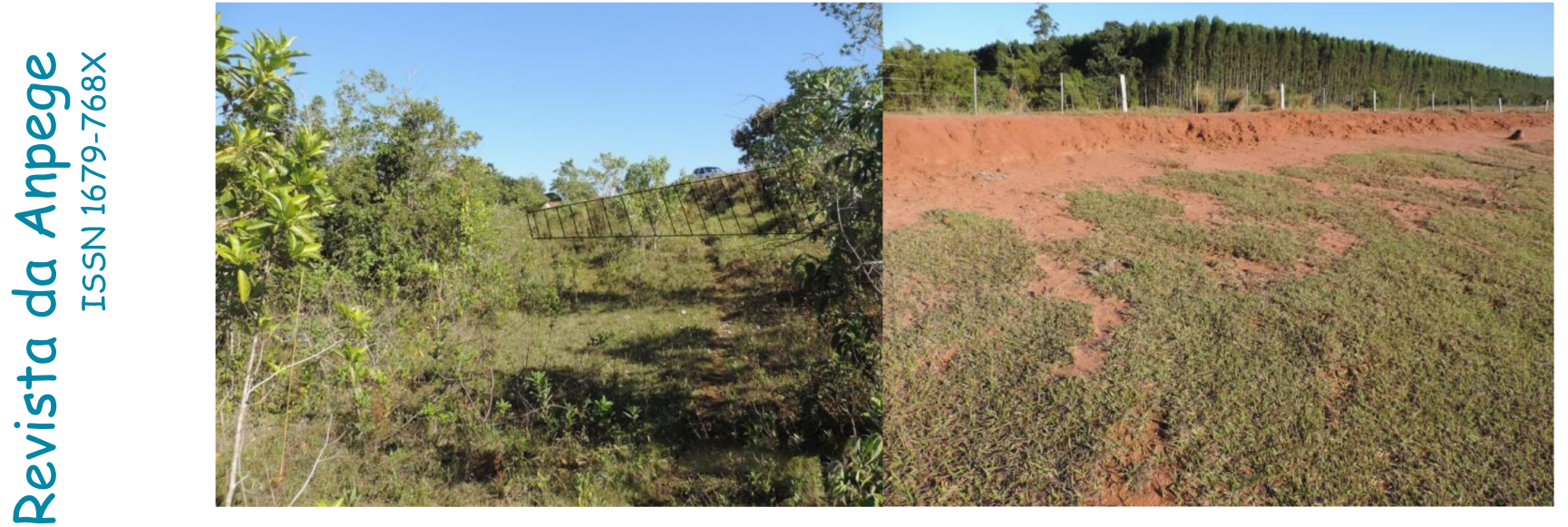


Principalmente nas estações chuvosas é possível a constatação, por meio das informações contidas nestes mapeamentos, da importância da manutenção de estradas que estão localizadas nesta classe, como também nas demais classes de Erosividade que necessitam de algumas formas de conservação, sobretudo no alto e médio curso da bacia hidrográfica, e que poderão ocorrer problemas erosivos se não for realizada a manutenção e implantação de caixas de retenção ao longo das estradas, como mostra a Figura 18 e 19.

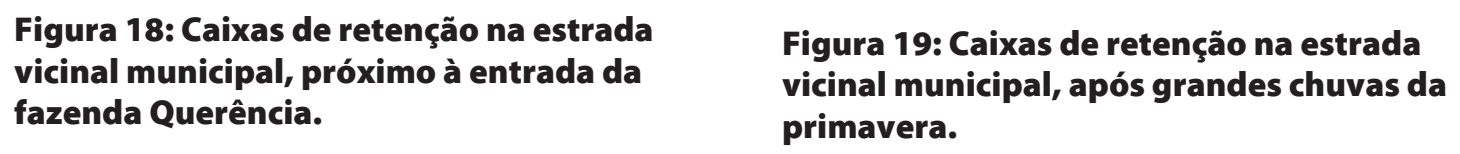

Figura 19: Caixas de retenção na estrada vicinal municipal, após grandes chuvas da primavera.

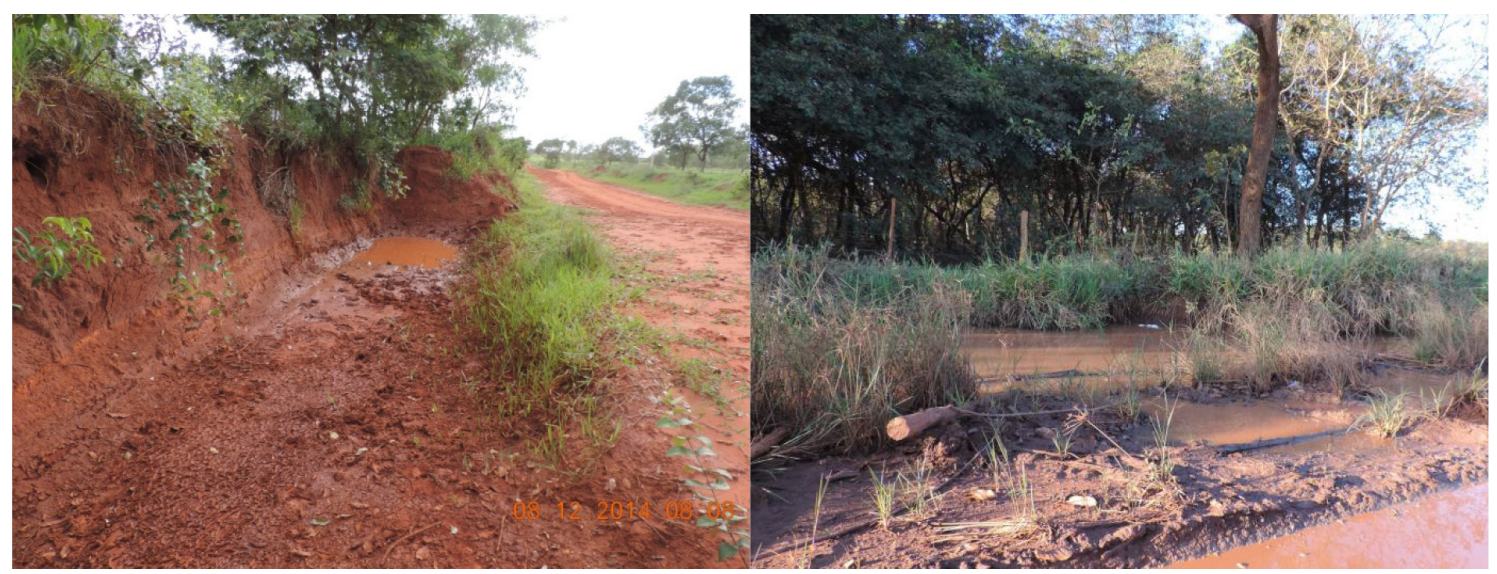

Estas caixas de retenção, ao redor das estradas vicinais, são obras realizadas com a principal finalidade, de ser um reservatório, assim, a captação de água e sedimentos é constante durante as chuvas, favorecendo a manutenção destas estradas, que em grande maioria da $\mathrm{BHCM}$, não apresentam asfalto. Dessa forma, a água não transcorre pelo leito da via, reduzindo as ocorrências das erosões.

\section{CONCLUSÕES}

Por meio dos dados obtidos, mostra-se que a identificação e mapeamento das áreas mais suscetíveis às erosões, constituindo em um importante instrumento, pois a condição de cada unidade atuante no sistema BHCM, depende das demais unidades, oferecendo assim, pesos distintos de influência sobre seu produto final, ou seja, a Erosividade.

Assim, a energia potencial erosiva pluviométrica ficou mais elevada na primavera, devido principalmente às chuvas ocorridas em outubro e novembro, chegando à 53,75 milhões de MJ.mm/bacia e sendo classificada como Peso 6 de Erosividade. Por outro lado, de acordo com a prévia climatológica, o inverno é a estação com menor potencial erosi- 
vo, entretanto, em 2014 o outono obteve esta classificação, chegando à 17,17 milhões de MJ.mm na BHCM.

Assim como a precipitação ocasiona a Erosividade, o relevo por si só oferece um potencial erosivo extremamente alto, dependendo de seu declive e comprimento de rampas (dissecações horizontal e vertical). Com isso, foi possível constatar que a BHCM possui $77,85 \%$ de suas áreas com relevo plano a suave, com declives de 0 a 6\%, que impõem pequenas limitações de uso de suas terras para declives de 3 a 6 , pois será preciso ações de controle erosivo ou de melhoria na fertilidade do solo.

As rampas encontradas ao longo da BHCM, com as dissecações horizontal e vertical, mostraram a maior presença das classes de 100 a 500 metros (horizontal) e das classes de 0 a 50 metros (vertical). Portanto, foi possível analisar que a energia potencial erosiva do relevo foi maior nas áreas próximas ao ponto 1 , devido aos declives mais acentuados e dissecação vertical com altos valores.

Com isso, apresentou-se como maior classe de abrangência, a Energia Potencial Erosiva do Relevo Fraca, que ficou disposta ao longo de toda a BHCM, obedecendo sempre uma ordem constatada de influência, com a declividade mais atuante sobre estes valores obtidos.

Nesta pesquisa é realizada uma análise do potencial erosivo do relevo e das precipitações, contudo, é necessária uma análise do que realmente ocorre de perda de solo na BHCM, para isto, faz-se necessário o monitoramento da velocidade, vazão e transporte de sedimentos em suspensão ao longo dos onze pontos de coleta das águas, nas estações do ano de 2014, demonstrando assim, que a energia erosiva de transporte de sedimentos em suspensão da BHCM acabou não oferecendo grandes valores de forma pontual, sendo apontada na maioria dos onze pontos de coleta das águas, a Classe I, que atinge apenas de 0,00 a $1,00 \mathrm{~g} / \mathrm{m}^{3} / \mathrm{s}$ de sedimentos transportados. Alcançando apenas valores altos, quando ocorre alguma anomalia de vazão, velocidade, ou alguma ocorrência antrópica.

Os valores alcançados pela energia potencial erosiva pluviometria, energia potencial erosiva do relevo e a energia erosiva do transporte de sedimentos em suspensão, tornaram-se possíveis os mapeamentos da Erosividade da BHCM, apontando que seus índices variaram, sobretudo nas classes intermediárias, mas foi possível visualizar que as classes alternaram conforme as chuvas e transporte de sedimentos, que por serem estacionais, favoreceram esta variação e apontaram que no verão e primavera, a classe de maior abrangência foi Fraca. Contudo, com a redução do transporte de sedimentos e precipitações, o outono e inverno apresentaram a classe Moderadamente Fraca como a mais abrangente, estas áreas foram encontradas em sua grande maioria, na sub-bacia do ponto 7 (médio curso). 
Por meio das adaptações realizadas durante os mapeamentos, buscou-se um aprimoramento das metodologias utilizadas, com a inserção de novos parâmetros, como a junção entre a precipitação, declividade, dissecação horizontal e vertical e a energia do transporte de sedimentos. Parâmetros estes, que acabaram auxiliando na obtenção de um produto detalhado, que retratou de forma concreta, a atual situação da área de estudo.

\section{REFERENCIAS}

1. BERTONI, J. \& LOMBARDI NETO, F. Conservação do solo. 2.ed. São Paulo, Ícone, 1999. 355p.

2. CHRISTOFOLETTI, A. Geometria hidráulica. Notícias Geomorfológicas, v. 16, n. 32, p. 3-37, 1976.

3. G__ Geomorfologia fluvial. São Paulo: Edgard Bluncher, 1981.

4. G__ Geomorfologia. São Paulo, Edgard Blücher, 2 ${ }^{\mathrm{a}}$ edição, 1980.

5. CREPANI, E.; MEDEIROS, J.S. de; HERNANDEZ FILHO, P.; FLORENZANO, T.G.; DUARTE, V.; BARBOSA C.C.F. - Sensoriamento Remoto e Geoprocessamento Aplicados ao Zoneamento Ecológico Econômico e ao Ordenamento Territorial. São José dos Campos, Junho de 2001 (INPE 8454-RPQ/722).

6. ESRI 2011. ArcGIS Desktop: Release 10. Redlands, CA: Environmental Systems Research Institute.

7. KNIGHTON, D. Fluvial forms \& processes: a new perspective. London: Arnold, 1998. 383p.

8. Fluvial forms and processes. Edward Arnold, London. 1984. 218p.

9. LEPSCH, I. F. Formação e conservação dos solos. São Paulo: Oficina de Textos, 178 p. 2002.

10. LOMBARDI NETO F.; MOLDENHAUER. W. C. Erosividade da chuva sua distribuição e relação com perda de solo em Campinas, SP. Bragantina, Campinas V.51, n.2, p. 189 - 196, 1992.

11. MENDES, I. A. A dinâmica erosiva do escoamento pluvial na bacia do Córrego Lafon Araçatuba / SP. 1993. 171 f.: Tese (Doutorado) - Faculdade de Filosofia, Letras e Ciências Humanas, USP, São Paulo.

12. NASA. Imagens de radar SRTM In: USSG: Science for a Changing World. Disponível em: $<$ http:// dds.cr.usgs.gov/srtm/version2_1/SRTM3/South_America/>. Acesso em 25 de Dezembro de 2014.

13. PEREIRA, A. R; ANGELOCCI, L. R; SENTELHAS, P. C. Agrometeorologia fundamentos e aplicações práticas. Guaíba - RS: Agropecuária, 2002. 478p.

14. PINTO, A. L., CARVALHO, E. M de, SILVA, P. V. Contribuição do subsistema biofísico e sócioprodutivo no planejamento territorial e gestapo ambiental da bacia do Córrego Fundo. In: VI Encontro Nacional da ANPEGE. Fortaleza, 2005. Anais.... Fortaleza: UFC, 2005.

15. PINTO, A. L.: MAURO, C. de; A importância do Ribeirão Claro para o Abastecimento de água da cidade de Rio Claro-SP. Geografia Teorética. Rio Claro, v. 15, 1985: p. 104-117. 
16. PINTO, André L.; LORENZ SILVA, J. L.; FERREIRA, A. G.; BASSO, P. M. Subsidio Geológico/ Geomorfológico ao ordenamento do uso, cobertura e manejo do solo, visando à redução da perda de solo e a recuperação da qualidade das águas superficiais da Bacia do Córrego Bom Jardim, Brasilândia/MS. Relatório Final FUNDECT/MS. UFMS. Três Lagoas, 2010: 147p.

17. PINTO, André L.; LORENZ SILVA, J. L.; FERREIRA, A. G.; BASSO, P. M. Subsidio Geológico/ Geomorfológico ao ordenamento do uso, cobertura e manejo do solo, visando à redução da perda de solo e a recuperação da qualidade das águas superficiais da Bacia do Córrego Bom Jardim, Brasilândia/MS. Relatório Parcial FUNDECT/MS. UFMS. Três Lagoas, 2009: 42p.

18. RAMALHO-FILHO, A.; BEEK, K. J. Sistema de avaliação da aptidão agrícola das terras. 3. ed. Rio de Janeiro: EMBRAPA-CNPS, 1995. 65 p.

19. SPIRIDONOV, A. I. Princípios de la metodologia de las investigaciones de campo y El mapeo geomorfológico. Havana: Universidad de la Havana, Faculdad de Geografia, 1981. 3v.

20. TRICART, J. A geomorfologia nos estudos integrados de ordenação do meio natural. Boletim Geográfico. Rio de Janeiro, v. 34, n. 251. out./dez. p. 15-42. 1976.

Artigo recebido em 03 de junho de 2016.

Artigo aceito em 10 de julho de 2016. 